
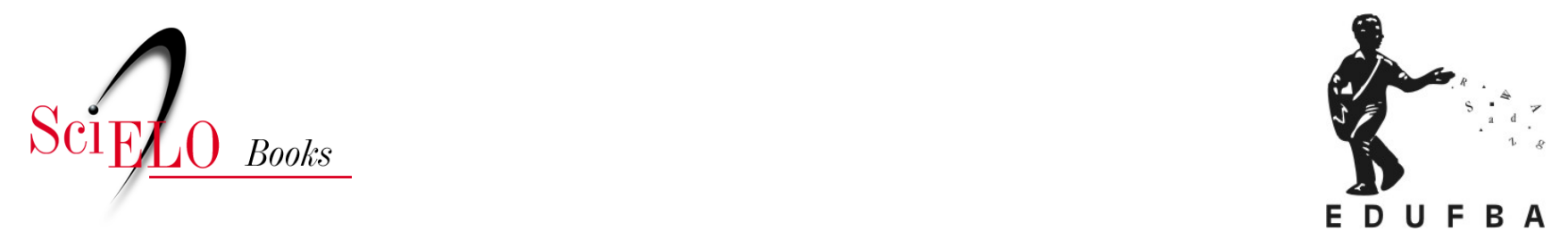

\title{
Os modelos analíticos, sua adequação ao uso do crack e a "communitas" dos usuários
}

\author{
Ygor Diego Delgado Alves
}

\section{SciELO Books / SciELO Livros / SciELO Libros}

ALVES, Y.D.D. Os modelos analíticos, sua adequação ao uso do crack e a "communitas" dos usuários. In: Jamais fomos zumbis: contexto social e craqueiros na cidade de São Paulo [online]. Salvador: Edufba: Cetad, 2017, pp. 137-226. Drogas: clínica e cultura collection. ISBN: 978-85-2321859-1. https://doi.org/10.7476/9788523218591.0006.

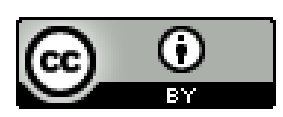

All the contents of this work, except where otherwise noted, is licensed under a Creative Commons Attribution $\underline{4.0 \text { International license. }}$

Todo o conteúdo deste trabalho, exceto quando houver ressalva, é publicado sob a licença Creative Commons Atribição 4.0. 


\section{OS MODEL OS ANALÍIICOS, SUA ADEQUACZ̃̃O AO USO DO CRACK E A "COMMUNITAS" DOS USUÁRIOS}

"Nós somos a nova Jerusalém."79

São constantes os debates acadêmicos sobre o uso de drogas nos quais o contexto social em que este uso ocorre aparece apenas e tão somente como uma citação obrigatória da tríade: substância - indivíduo - sociedade. Disserta-se sobre a substância e sua ação sobre um organismo, quando muito considerando-se um ou outro aspecto da psique, porém, muito pouco ou quase nada se diz a respeito da situação do usuário no ambiente com que ele interage e sua influência sobre os efeitos da droga e os padrões de seu uso.

Este capitulo apresenta uma sequência de autores que no decorrer da segunda metade do século XX, desenvolveram um proficuo arcabouço teórico destinado a dar conta de ricas pesquisas com usuários de maconha, LSD, cocaina e heroína. Todos eles preocupados com a influência do meio social no aprendizado, efeitos, quantidade e propósitos de uso. São eles, o sociólogo norte-americano Howard Becker, e o psicanalista e psiquiatra, também estadunidense, Norman Zinberg.

As obras desenvolvidas pelos autores mais que se completam, elas compõem entre si um fluxo de pensamento. São produto de pesquisas que se sucedem e procuram, cada uma a seu modo, dar continuidade e superar desafios não plenamente resolvidos nos trabalhos anteriores. Assim será com Zinberg em relação à pesquisa de Becker com fumantes de maconha. Zinberg estará diretamente preocupado em como os rituais e regras presentes nas práticas de consumo de drogas ajudam na autorregulação destas mesmas práticas.

79 Corintiano. 


\section{0 modelo de Howard Becker e o uso do crack}

Após descrevermos o uso do crack, sua parafernália e as forças em seu entorno, podemos nos dedicar a analisar este uso a partir da literatura antropológica voltada ao consumo de drogas, na qual se destaca como pioneiro, Howard Becker. Em sua obra sobre o desvio, intitulada de Outsiders, Becker questiona a ideia de que a motivação ou mesmo predisposição ao uso de drogas seria derivada de suposta presença de algum traço psicológico particular. Para ele, esta seria a forma corriqueira de considerar o uso de drogas, presente em um grande número de teóricos, particularmente os estudiosos da maconha. Segundo eles, o uso derivaria de certa "necessidade de devanear e fugir de problemas psicológicos que o indivíduo não é capaz de enfrentar". (BECKER, 2008, p. 51) Em sua pesquisa, ele entrevistou 50 usuários de maconha, sendo metade músicos de jazz e o restante da amostra obtida por contatos inicialmente fornecidos pelos músicos.

Becker delineia sua visão a respeito do uso da maconha baseando-se no desvio, com motivos desviantes se desenvolvendo no curso da experiência com a atividade desviante (fumar maconha), em um movimento inverso ao proposto pela psicologia. Assim, para ele, o comportamento desviante acabaria por produzir a motivação desviante. Os impulsos e desejos vagos do neófito curioso são, no decorrer de sucessivas seções de uso, transformados em padrões mais definidos de ação por meio da interpretação social de uma experiência física, inicialmente ambígua. O padrão de uso da maconha de alguém - se ele continua ou não usuário, se usa mais ou menos da substância - seria uma decorrência de sua concepção a respeito desta substância psicoativa desenvolvida através da experiência no grupo de usuários. Vejamos isto de modo mais detido. 
Figura 18 - A interpretação social da experiência física

\section{Atividade/Experiência desviante}

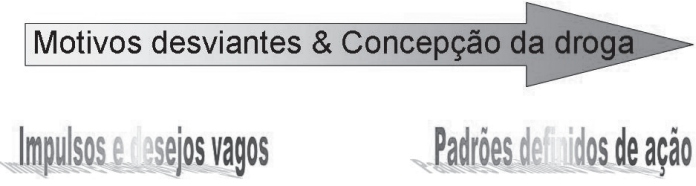

Fonte: Coleção particular do autor.

$\mathrm{Na}$ carreira do usuário procura-se compreender, a partir do desenvolvimento da experiência física e do modo como ele reagirá aos controles sociais existentes em torno da droga, "a sequência de mudanças na atitude e na experiência que leva ao uso de maconha por prazer" (BECKER, 2008, p. 52) (padrão recreativo, casual, não compulsivo). ${ }^{80}$ Dois problemas que aparecem ao se pretender inferir o uso de alguma droga a causas (traços) psicológicas. Primeiramente, muitos usuários não apresentam tais traços causadores e, em segundo lugar, a dificuldade encontrada por este modo de conceber o problema para dar resposta à grande variabilidade do comportamento em relação à droga, em um dado indivíduo, no decorrer tempo (a carreira do usuário). A mesma pessoa pode ser incapaz de usar a droga por prazer em determinado momento e ser capaz de fazê-lo no estágio seguinte, para mais tarde, retornar à primeira forma. Tais variações tornam-se compreensiveis como consequências de mudanças na concepção que o usuário tem da droga, passando, por exemplo, de alguém inicialmente inadaptado ao uso a alguém capaz de vislumbrar no uso de

80 O uso do crack também é por prazer. Mesmo para aqueles em situação de rua como se encontravam muitos de nossos interlocutores, o objetivo é dar um "bom trago" e não apenas saciar a fissura ou a abstinência. Isto seria, por exemplo, objeto do primeiro "trago" de uma pedra de seis "tragos". Os demais são fumados de modo prazeroso pelo craqueiro. 
Jamais fomos zumbis

determinada substância uma fonte de prazer. Desta maneira, Becker tenta alcançar uma:

[...] formulação geral da sequência de mudanças de atitude e experiência que sempre ocorriam quando o indivíduo tornava-se desejoso e capaz de usar maconha por prazer e nunca ocorria ou não era permanentemente mantida quando a pessoa não estava disposta a usar maconha por prazer. (BECKER, 2008, p. 54)

Portanto, existe uma carreira de uso. ${ }^{81} \mathrm{O}$ termo e o conceito de carreira foram trazidos por Becker da literatura de administração de empresas, particularmente da administração de recursos humanos, onde se tratava da carreira dos funcionários em uma empresa ou no Estado e as mudanças daí advindas. Assim, a experiência com o uso de uma substância é dada através do tempo e não apenas pontualmente - de uma única experiência de experimentação da maconha - porque para tornar-se um maconheiro "de sucesso", ou seja, aquele capaz de usá-la por prazer, se faz necessário insistir no uso mesmo em detrimento de uma má experiência. Neste trajeto percorrido ao longo da carreira de uso, uma série de mudanças de atitude com relação à maconha e ao grupo de usuários e não usuários vão se dando.

Becker focalizou em seu trabalho, o histórico da experiência do usuário com a maconha "procurando mudanças importantes em sua atitude com relação a ela e no seu uso efetivo e as razões dessas mudanças". (BECKER, 2008, p. 55) Assim como nós procuramos fazer neste livro, quando foi possivel e apropriado, ele usou o "jargão" nativo. Becker irá deter-se sobre três momentos de aprendizado, não necessariamente distintos:

81 Becker em seu estudo escolheu a maconha entre outros motivos por ser uma droga para ele incapaz de produzir síndrome de abstinência, o uso daí decorrente - das drogas capazes de produzir abstinência - é para aliviar seus sintomas de retirada. No caso do crack, nos foi relatado seu uso para aliviar a fissura, porém, é certo que se permanece fumando muito além do simples alivio destes sintomas e principalmente, fuma-se crack sem a necessidade de se sentir fissura alguma. 
o aprendizado das técnicas de uso da maconha, o desenvolvimento da capacidade de perceber os efeitos e finalmente, como aprender a gostar destes efeitos. O neófito, no mais das vezes, não sente, nem aproveita os efeitos da maconha na primeira oportunidade de uso. Se nada acontece, não é possivel "desenvolver uma concepção da droga como um objeto que pode ser consumido por prazer, e, portanto, o uso não continuará." Assim, "[...] ele precisa aprender a empregar a técnica adequada de fumar, de modo que seu uso da droga produza efeitos em termos dos quais sua concepção sobre ela possa mudar". (BECKER, 2008, p. 56) Tal mudança seria o resultado da participação do novato em grupos de usuários.

Figura 19 - Uso de maconha por prazer - Aprendizados

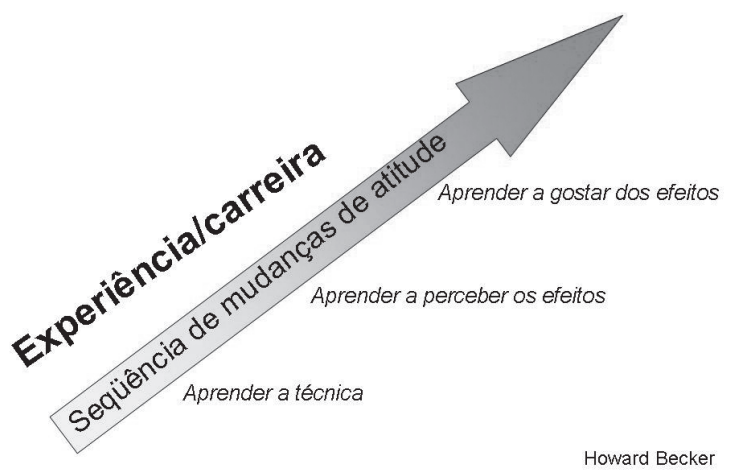

Fonte: Coleção particular do autor.

A iniciação abaixo, do primeiro uso de crack por parte de Esmeralda do Carmo Ortiz, mencionada anteriormente, presente em sua obra Porque não dancei, guarda semelhanças com o esquema de Becker e podemos perceber isto, nesta descrição:

Eu tinha 13 anos e dei o primeiro pega de verdade. Ficou um barulho estranho na minha cabeça. Eu fumei só por fumar e disse que não ia fumar mais nada. Eu 
disse: 'Vamos cair na correria, que é o seguinte, vamos se adiantar, se atrasar não dá'. Ela disse: 'Não, vamos catar mais uma. Quanto você tem aí?'. Eu falei: 'Tenho 15 paus, meu'. E ela: 'Pô, vamos fumar mais uma pedra'. Falei que aquele barato não dava porra nenhuma. Ela insistiu pra gente pegar mais uma pedra pra fumar. Eu falei que não estava a fim, mas ela insistia. Então eu fui e peguei mais um 'pino', que a gente chama também de 'papel', uma pedra de crack. Nós fumamos aquele papel. No primeiro pega não deu nada, no segundo pega não deu nada, no terceiro pega ela colocou o maior montão pra mim. Eu falei pra colocar pouco, que eu tinha medo de overdose, medo que a minha língua enrolasse. Eu colocava a língua pra fora, olhava pros lados, pra ver se não tinha polícia e falava: 'Sandrão, segura minha língua que eu vou dar um pega'. Não tinha como, tinha que colocar o cachimbo na boca, então comecei a entrar na 'nóia' que eu ia morrer de overdose. Fiquei morrendo de medo, de medo, de medo [...] Depois vi que não tinha morrido. [...] Catamos mais um papel e fumamos. Eu fiquei na light, numa boa. (ORTIZ, 2001, p. 95)

Percebemos claramente na exposição acima, da primeira experiência de uso de crack por Esmeralda, a falta de motivação inicial clara para o uso da droga ao afirmar: "fumei só por fumar e disse que não ia fumar mais nada". Vemos como sequer há uma vontade nítida de busca pelos efeitos e um grande esforço é preciso para a realização de novas tentativas com a necessidade de vencer o medo em momentos sucessivos, a partir da ajuda de uma usuária experiente. O efeito inicial do uso do crack encontra-se aí, muito distante da ideia pertencente ao senso comum a respeito da droga: a de um início inesquecível e ultra prazeroso o qual se continuaria buscando infrutiferamente nos usos posteriores. Como se a primeira experiência fornecesse um prazer absolutamente indescritivel e inigualável fazendo do pobre neófito um condenado à eterna busca infrutífera pela repetição impossivel do gozo inicial.

"O efeito é rápido, fazendo com que o usuário fique vulnerável à dependência logo na primeira vez que experimenta, 
despertando a vontade de usar cada vez mais. [...] O crack é a droga mais devastadora e pode provocar dependência desde a primeira pedra." (VIVA SEM DROGAS, 2014)

Esta crença, carente de comprovação empírica, pode influenciar no aumento do estigma sobre o usuário inicial da droga, tido como alguém definitivamente comprometido com a repetição deste uso até suas consequências mais profundamente danosas.

A degradação acontece em uma velocidade incontrolável, o usuário deseja droga a qualquer custo, sendo capaz de gastar todo o dinheiro, roubar coisas de casa para vender, se prostituir e até cometer crimes como furtos e roubos para sustentar a dependência. (VIVA SEM DROGAS, 2014)

Porém, vimos como o uso inicial do crack se assemelha ao esquema de drogas consideradas muito menos danosas como a maconha. O neófito não sente, necessariamente, os efeitos imediatamente após o primeiro uso e necessita da colaboração, confiança e incentivo de um usuário mais experiente para aprender a sentir os efeitos da droga. Isto é possivel a partir da superação das crenças negativas sobre o uso do crack adquiridas anteriormente, fora do grupo de usuários, como a crença vista aqui, da morte iminente por overdose: "Eu falei pra colocar pouco, que eu tinha medo de overdose, medo que a minha língua enrolasse”. (ORTIZ, 2001, p. 95)

No uso da maconha estudado por Becker, sentir os sintomas e vinculá-los à droga pode dar ao usuário, mesmo aquele novato no uso, a certeza íntima, porém, reafirmada e confirmada pelo grupo de pares, de ter sentido os efeitos da cannabis. Assim, “[...] um 'barato' consiste de dois elementos; a presença de sintomas causados pelo uso da maconha e o reconhecimento desses sintomas e sua vinculação, pelo usuário, com o uso da droga”. (BECKER, 2008, p. 57) De modo geral, pela observação dos que tem barato, o neófito insiste na experiência até obter e identificar os sintomas; ele aprende alguns "referentes 
concretos do termo 'barato' e aplica essas noções à sua própria experiência". (BECKER, 2008, p. 59) Como nos ensinou o usuário de crack Salomão, já mencionado anteriormente, enquanto estávamos no "morrinho": “A 'brisa' boa é quando dá um 'tuim", e por “tuim”, podemos entender um zumbido agudo nos ouvidos. ${ }^{82} \mathrm{Um}$ termo êmico para o ato de fumar crack é "dar uma paulada" devido à força atribuída ao efeito da droga. Estes referentes concretos dados no corpo do usuário, em sua percepção da realidade, das cores a sua volta, dos sons, as mudanças de humor características e desejadas, são todos passíveis de indicar para ele diferentes sensações que poderiam ser associadas com o uso da droga. Assim, um passo importante no uso de maconha por prazer, ou seja, aprender a sentir os efeitos, pode ser esquematizado conforme o diagrama abaixo:

Figura 20 - Uso de maconha por prazer - Efeitos Aprender a perceber os efeitos

\section{O "barato"}

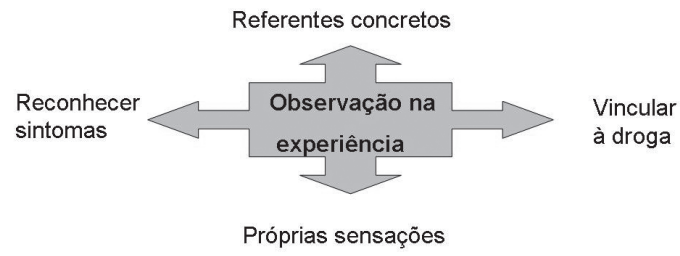

Fonte: Coleção particular do autor.

Uma vez reconhecidos os efeitos, trata-se agora de aprender a apreciá-los. O gosto pela experiência de fumar maconha é socialmente adquirido no grupo de pares e não algo dado de

82 Chegamos a ouvir o tal zumbido em uma de nossas ocasiões de uso durante a pesquisa de campo e imediatamente pudemos associá-lo a uma sensação agradável pela nossa orientação pregressa dada por Salomão. Esmeralda também parece ter ouvido: "Ficou um barulho estranho na minha cabeça”. (ORTIZ, 2001, p. 95) 
antemão como traço de personalidade, como presumido nas abordagens psicológicas criticadas por Becker. Ao investir em sua carreira de usuário de maconha "de sucesso", as sensações porventura desagradáveis, sentidas pelo novato em seu processo de aquisição de experiências de uso, deverão ser redefinidas para a continuidade deste mesmo uso. Isto se dá tipicamente em interação com usuários mais experientes capazes de minimizar a gravidade das sensações desagradáveis e chamar atenção para aspectos mais prazerosos e reconhecíveis dos efeitos. Por observar outros fazerem uso e constatar seu sucesso em usar por prazer é possivel ao novato tranquilizar-se em meio a uma experiência ambígua como vimos no caso de Esmeralda. Mesmo uma experiência desagradável poderá ser redefinida como algo agradável, prazeroso e até mesmo desejável depois do gosto pela droga - seja ela maconha ou crack - ter-se desenvolvido. "O prazer é introduzido pela definição favorável da experiência que uma pessoa adquire de outras" (BECKER, 2008, p. 65) na interação. Assim, uma nova concepção a respeito das sensações percebidas, adquirida na interação, torna possivel a redefinição positiva da experiência com a droga. Contudo, caso, após uma experiência negativa, não seja possivel ao sujeito redefinir o uso como capaz de produzir prazer, ele poderá cessar. Caso contrário, a carreira poderá evoluir como na figura a seguir:

Figura 21 - Uso de maconha por prazer - Interação

\section{Aprender a gostar dos efeitos}

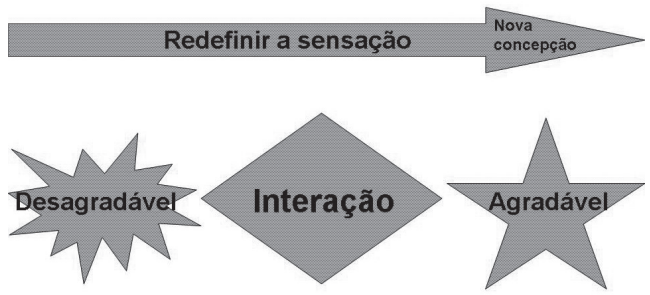

Fonte: Coleção particular do autor. 
Jamais fomos zumbis

Assim, alguém só se torna usuário após desenvolver uma disposição ou motivação que não poderia estar presente no início do uso, "pois envolve concepções da droga que só seria possivel formar a partir do tipo de experiência real". (BECKER, 2008, p. 67) Esta seria a experiência de aprender a usar e sentir a produção de efeitos reais, aprender a reconhecer estes efeitos e associá-los ao uso, e, finalmente, aprender a gostar das sensações percebidas. A partir daí, os controles externos sobre o neófito, controles estes que operam para valorizar certas formas de comportamento em detrimento de outros, como fumar maconha, podem entrar em colapso. Isto ocorre por consequência do ingresso em um "grupo cuja cultura e controles sociais próprios operam em sentido contrário aos da sociedade mais ampla" (BECKER, 2008, p. 69), emancipando-o destes controles e sensibilizando-o aos do grupo restrito de usuários da droga.

O neófito, no trabalho de Luana Malheiros (2012) sobre o uso de crack em Salvador, se assemelha ao perfil do "nóia", termo êmico ou nativo para designar o praticante do uso descontrolado. Ele se contrapõe ao "usuário", termo êmico que designa aquele capaz de fazer um uso controlado de crack. O "nóia", geralmente um neófito, faz uso em qualquer lugar, sem selecionar o ambiente e horário mais propício ao melhor aproveitamento dos efeitos do crack, além de usar na companhia de quem quer que seja e abandonar todos os seus compromissos em prol do uso. Claramente, no caso do "nóia", os controles externos entraram em colapso e ele passou a compartilhar um estilo de vida semelhante ao de outros usuários na mesma situação. Para modificar este estado de "coisas", outros controles externos se farão necessários para impor limites ao uso de crack. Porém, como Becker não tratou de uma droga da qual seja comum o uso abusivo, mas da maconha, estes controles serão mais bem tratados à frente, quando entrarmos em maior contato com a obra de Zinberg. 
Controles sociais afetam o comportamento pelo manejo de diferentes instâncias de poder e pela aplicação de sanções; também o fazem pela recompensa e punição de comportamentos valorizados e desvalorizados. Mas, no uso de drogas, surgem ainda controles mais sutis de influência "sobre as concepções que as pessoas têm da atividade a ser controlada". (BECKER, 2008, p. 69) Estas concepções são comunicadas em situações sociais, na interação com pessoas "consideradas respeitáveis e validadas pela experiência”. (BECKER, 2008, p. 70) Ou seja, os capazes de emprestar seu prestígio ao comportamento e às concepções valorizadas, particularmente em um grupo desviante. As sanções da sociedade abrangente se tornam ineficazes quando ocorrem eventos geradores de experiências apropriadas para alterar certas concepções, tornando adotar o comportamento desviante concebivel para a pessoa. Portanto, existe uma sequência de eventos e experiências na gênese do comportamento desviante capazes de suplantar os controles sociais que atuam no propósito de evitá-lo, como na figura abaixo:

Figura 22 - Uso de maconha por prazer - Carreira

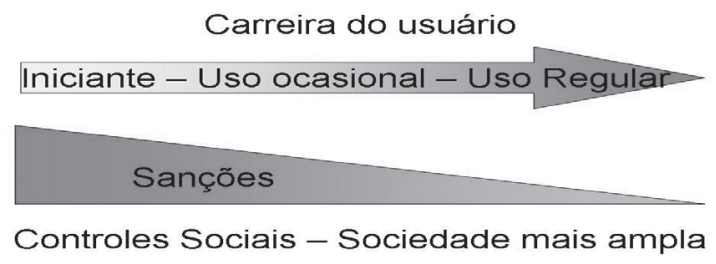

Howard Becker

Fonte: Coleção particular do autor.

Estes controles ou sanções da sociedade mais ampla partem da ilegalidade do ato e das severas punições passiveis dele advir, como a prisão. Assim como os controles e sanções podem surgir da atribuição aos usuários de maconha das característi- 
cas estigmatizantes associadas ao hábito. Como irresponsabilidade, falta de controle, ou mesmo loucura, além de outros tipos de sanções informais como ostracismo ou retirada do afeto por parte de entes queridos. Fazem parte destes controles a força das ideias ou concepções definidoras do uso da droga como violação de imperativos morais, ou ainda, como perda de autocontrole, paralisia da vontade e até escravidão.

Figura 23 - Uso de maconha por prazer - Carreira

\section{Controles sociais ou sanções sociais}

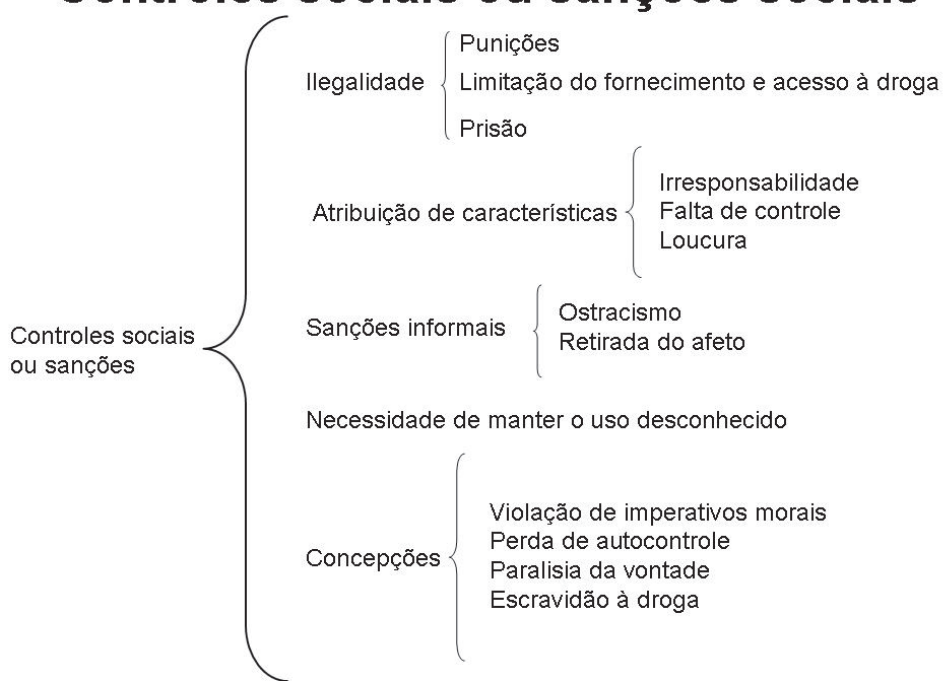

Fonte: Coleção particular do autor.

O pânico moral em torno do crack irá valer-se de muitas características do controle social descritas acima. Na sua relação com os controles da sociedade mais ampla e com a subcultura da droga, a carreira do usuário pode ser dividida em três estágios. O primeiro estágio é o de usuário iniciante; o segundo estágio é o de uso ocasional, esporádico; o terceiro de usuário regular, ou rotineiro. Em uma carreira de usuário de maconha 
bem-sucedida, os controles sociais do grupo desviante e os da sociedade mais ampla vão respectivamente ganhando e perdendo espaço de influência sobre o usuário. Quanto mais o uso deixa de ser ocasional e aumenta sua regularidade, mais este usuário ocasional fica cada vez menos receptivo às concepções a respeito da droga contrárias às do grupo desviante.

Figura 24 - Uso e controle social

\section{Carreira do usuário}

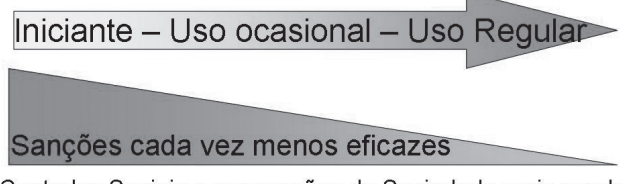

Controles Sociais e concepções da Sociedade mais ampla

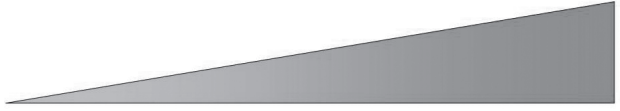

Controles sociais e concepções do grupo desviante

Fonte: Coleção particular do autor.

Porém, em nossa pesquisa sobre o uso do crack pudemos observar como o pânico moral, ou a ausência dele, no período anterior ao final dos anos 1990 do século passado, teve influência sobre a maior ou menor dificuldade para iniciar o uso do crack. Antônio é um ex-usuário cujo início de carreira se deu em meados dos anos 1990, mais precisamente em 1996 e não teve ele de enfrentar maiores receios ao iniciar o uso do crack. Segue abaixo, as suas declarações:

Antônio - Eu sou um caso à parte. Acho que todos os usuários de crack são um caso à parte. Cada um teve uma história de começo. E eu penso que esta história de começo, justamente nesse ponto que você fala sobre a concepção da questão do crack, penso que isso varia de círculo social. Meu círculo social estava como que normalizando, ou não tava [sic] colocando o fato do crack como uma coisa pesada, mas como mais uma droga. Eu não tinha visto 
ninguém usando; para mim era novo, 1996 era novo. Eu não sabia das consequências. Não tinha tanto 'nóia' na rua, não tinha tantos indícios de roubo por causa do crack, então, no imaginário social do meu grupo não tinha essa expectativa. Eu lembro que este círculo de amizade que começou a me apresentar essa porra desse crack, para eles isso era normal, normal não, era assim, uma droga pesada, uma vibe bem dark, sabe? Fui usar e não questionei sobre males e consequências porque não tinha em nosso círculo nenhum 'nóia'. Ninguém ficava virado, ninguém que roubava pra isso. Ninguém que tinha algumas consequências derivadas da droga, não tinha, não tinha. A galera não falava bem. Era outra vibe, o pessoal da escuridão, esse aqui é o pessoal da luz. Tinha uma certa separação e eram todos neófitos com respeito a... só tinha um que já usava bastante, mas ele não apresentava nenhuma característica de 'nóia'. Tinha controle. Nem se comentava isso na televisão, jamais, jamais.

Para dar início ao uso, foi aparentemente importante não haver usuários abusivos perceptiveis no grupo de neófitos, além disto, no caso de Antônio foi perfeitamente possivel iniciar o uso a partir de pouquissima experiência acumulada. Aqui, existe apenas um usuário mais experiente e mesmo assim, sua importância reside mais em não apresentar sinais de decadência que ser ele alguém capaz de ensinar a usar a droga. Assim, seu estado preservado e seu comportamento de usuário controlado contribuíram, aparentemente, para uma visão não tão negativa do crack e de ser seu consumo, algo possivel de usufruir sem maiores consequências deletérias. O fato de, naquela época, meados dos anos noventa, não haver ainda 'nóia' na rua nem tampouco furtos e roubos a eles associados, também parece colaborar para um início de uso da droga mais tranquilo.

No caso de Esmeralda, a falta de um modelo de usuário controlado imprimiu grande tensão à experimentação do crack. Rodeada por "nóias" - como são designados os usuários problemáticos em São Paulo - ela não possuía um modelo positivo capaz de tranquilizá-la quanto às consequências de usar crack e também quanto aos seus possiveis efeitos deletérios, como enrolar a lingua. Estes sintomas, de certa forma fantasiosa sobre os efeitos do crack, faziam parte das expectativas de Esmeralda 
e o modelo do "nóia" era para ela o comportamento esperado de quem fumasse. Ou seja, não existia para Esmeralda um modelo controlado de uso ao qual ela pudesse se apegar no futuro. Ao contrário, sua visão a respeito dos efeitos do crack e do próprio usuário eram as piores possiveis e em seu caso funcionaram, pelo menos em relação ao padrão "nóia" de consumo do crack, como uma espécie de expectativa auto realizada.

Retornando ao modelo de Becker, podemos ver como os vários tipos de controles sociais tornam-se cada vez menos eficazes na medida em que se avança na carreira de usuário. Assim se desenrola a consecutiva anulação de controles tais como: a limitação do fornecimento e acesso à droga, a necessidade de manter o uso desconhecido pelos não usuários e a definição do ato como imoral. Estes vão dando lugar às concepções do grupo desviante de usuários de maconha. No caso de Esmeralda, aparentemente, apenas as duas últimas destas três formas de controle operavam, pois, o acesso ao crack é praticamente livre na região central de São Paulo. Ela relata em seu livro a vergonha sentida após tornar-se "usuária forte" de crack.

O pior era que, quando amanhecia todo o pessoal que estava usando drogas comigo ia embora e só eu ficava ali, parecendo um bicho na ânsia de querer mais drogas. A loucura passava, a movimentação começava e eu ali, toda suja. Não aguentava ouvir o canto dos pássaros, aquilo me irritava, além da vergonha, pois as pessoas que passavam perto de mim atravessavam a rua ou saíam correndo, com medo de eu roubar as bolsas delas. Isso me irritava. (ORTIZ, 2001, p. 99)

Não é tarefa fácil manter o uso desconhecido pelos não usuários quando se está em situação de rua. Vimos acima, como o barraco é uma tecnologia de habitação e também forma de livrar-se do olhar acusatório do "Zé Povinho", aqueles que passavam perto de Esmeralda e saíam correndo com medo de serem assaltados. Mais que ser percebido como imoral, o uso do crack colocava Esmeralda em situação vexatória e isto a irritava. Possivelmente, a fazia ter o desejo de vingar-se dos tran- 
seuntes amedrontados levando-a a roubá-los mais uma vez e, em um processo retroalimentativo, o produto destes roubos forneceriam os fundos necessários para se fumar mais crack.

Para ter acesso à maconha, ainda no esquema de Howard Becker, deve-se geralmente participar de algum círculo não convencional, muitas vezes praticante de atividades e com valores opostos aos da sociedade mais ampla, capaz de tornar as fontes de fornecimento acessiveis. Ao afastar-se do grupo, o uso pode cessar pela falta de fornecimento, porém, uma vez usando dentro do grupo, os próprios controles internos sensibilizarão o novo usuário da necessidade de adquirir sua própria droga e não permanecer apenas sendo abastecido pelos demais. ${ }^{83}$

Figura 25 - Fontes de fornecimento

Fontes de Fornecimento

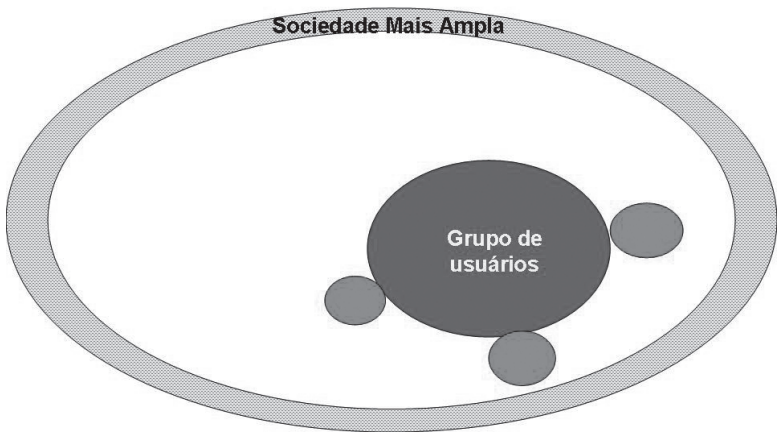

Fonte: Coleção particular do autor.

Para tanto, se faz necessário um "contato" e o conhecimento de onde encontrá-lo e de como apresentar-se para vencer qualquer hesitação à venda. Com a experiência aprende-se a avaliar o perigo próprio desta atividade ilegal e o risco deixa de impedir a compra. Então, o comprador passa a sentir-se seguro. O uso

83 No caso do uso do crack, o termo "parasita" parece retratar esta disposição. 
regular depende da estabilidade destas fontes de fornecimento e, a cada estágio, seja ele iniciante, ocasional ou regular, haverá um modo típico de fornecimento. "[...] a participação em grupos em que a maconha é consumida cria as condições nas quais os controles que limitam o acesso a ela deixam de operar". (BECKER, 2008, p. 75)

Vimos anteriormente, como o acesso ao crack é livre na região central de São Paulo, porém, isto não diminui a atração da fonte de fornecimento. Pelo contrário, ela é local de moradia de usuários de crack, como a "biqueira" a céu aberto, por nós pesquisada. A "biqueira", libertada das fronteiras do lote urbano, se projeta rua adentro para possibilitar uma maior proximidade com quem "é do crack" e lá, neste local de comércio e uso, através da tecnologia elaborada do barraco, alguns usuários podem ter sua moradia permanente e compartilhar não apenas da droga, mas, muito mais que isto, da vida na "biqueira". Veremos isto pouco mais à frente.

Figura 26 - Acesso ao fornecimento

\section{Fornecimento}

\begin{tabular}{lll}
\hline Iniciante - Uso ocasional - Uso Regular \\
Fornecimento & Início & Amplo acesso \\
feito pelo & da & a fontes \\
grupo & necessidade & de fornecimento \\
de usuários & de & \\
& fornecimento & \\
& próprio &
\end{tabular}

Fonte: Coleção particular do autor. 
Para os usuários de maconha pesquisados por Becker, o uso é limitado também pelo fato ou crença de que não usuários, cujo respeito e aceitação eles valorizam, caso venham a descobrir seu hábito, lhes apliquem sanções de algum tipo. Por isso, em sua maioria, os usuários de maconha são desviantes secretos e seus medos são contestados por racionalizações proporcionadas pela observação de usuários mais experientes, aparentemente impunes. Para o usuário ocasional, os pontos de contato com o mundo dos usuários regulares, que o convidam a se juntar a eles, parecem perigosos. Esta impressão se desfaz com o progresso exitoso na carreira de maconheiro, pela gradual, porém segura, substituição das concepções da sociedade ampliada pelas do grupo desviante. O neófito no uso, inicialmente encontra-se mais ligado à sociedade ampliada e seus pontos de vista sobre a droga e menos próximo do grupo de usuários, como podemos observar na figura abaixo:

Figura 27 - Sigilo do iniciante e usuário ocasional

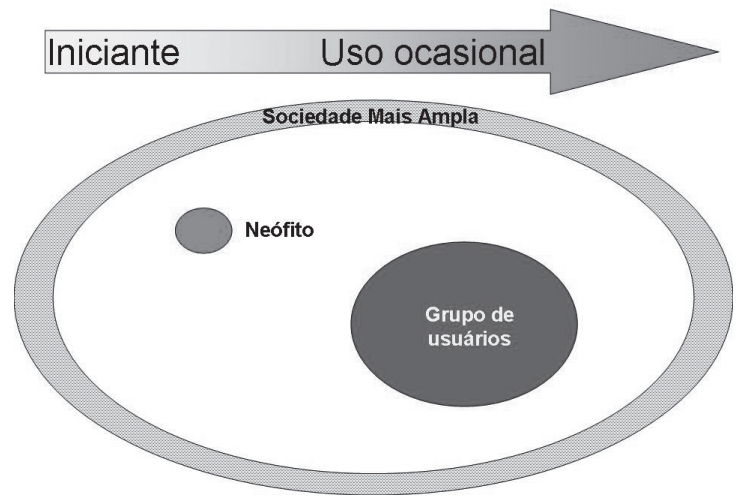

Fonte: Coleção particular do autor.

Quando o uso se torna regular, ocorre uma mudança na atitude deste novo usuário de maconha proveniente de uma mudança de concepção a respeito das oportunidades de consumi-la. 
Surge uma nova convicção a este respeito e ela passa a ser fumada sob o nariz dos não usuários, ou se adota um novo padrão de participação social que reduza quase totalmente as interações com os não usuários a niveis raros e sem importância. O uso regular só poderá permanecer caso se consiga lidar com os riscos de ser descoberto na posse da droga e ser capaz de esconder seus efeitos quando na presença de não usuários. Caso consiga controlar melhor os efeitos de seu uso com uma eficiente administração dos sintomas aparentes, capazes de denunciar o usuário ao não usuário de quem ele está desejoso de manter seu novo hábito em sigilo, ele poderá continuar a manter contato com estes não usuários. Porém, quanto maior a dificuldade em manejar sintomas como: confusão, olhos vermelhos, cheiro e dedos amarelados, mais o usuário regular será induzido a permanecer mais tempo com o grupo desviante. A própria fruição dos efeitos desejados a partir do consumo da maconha pode levar o usuário regular a se afastar de não usuários no intuito de melhor aproveitá-los. Administrar os sintomas em frente aos "caretas" pode consumir parcela importante do prazer em utilizar a droga.

Figura 28 - Sigilo no uso regular

Uso de maconha e controle social - Sigilo

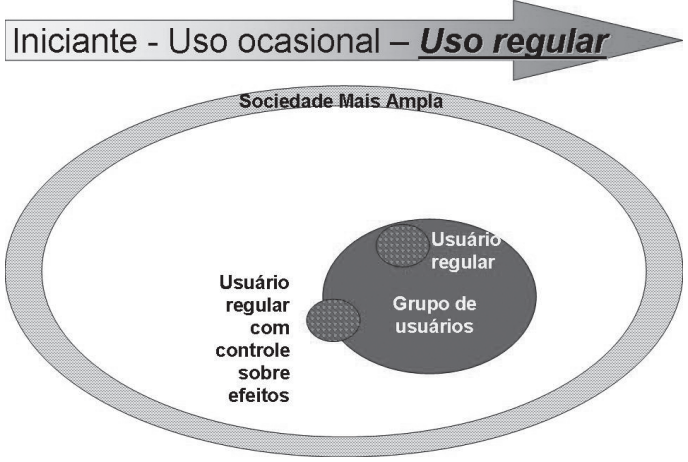

Fonte: Coleção particular do autor. 
Estes apontamentos de Becker a respeito da relação entre o usuário de maconha, os grupos de usuários e a sociedade mais ampla nos será de capital importância para procurarmos compreender o fenômeno da "biqueira" a céu aberto e mesmo a Cracolândia. Um usuário de crack da Cracolândia, de vulgo Mariano, com quem compartilhamos muito da "sintonia" em nosso processo de interlocução, nos revelou morar com sua avó, além de passar temporadas na Cracolândia. Lá, ele podia usar crack, o que era vedado em sua residência e fazia isto há mais de dez anos. Voltava à casa de sua avó regularmente, porém, os períodos na Cracolândia eram de duração superior. Como os outros frequentadores do local, ele se dedicava com afinco à "treta" e lá possuía seus "parças", inclusive um primo de vulgo Corintiano que também pudemos conhecer. Outro caso semelhante é o de Carazinho, o primeiro usuário de crack com quem tivemos interlocução na Cracolândia. Carazinho, como muitos outros membros da população flutuante do local, andava munido de uma mochila presa às suas costas. Nela carregava seus instrumentos de trabalho como pintor de paredes com compressor de tinta. Após receber o pagamento por algum serviço, dirigia- se à Cracolândia para consumir crack e rever os "parças". Quando terminava o dinheiro, poderia retornar ao trabalho abandonado, ou procurar nova ocupação temporária. Assim, a mochila nas costas e sua habilidade como pintor qualificado o permitiam um modo de vida desprendido de maiores vínculos. Assim como Mariano, Carazinho possuía local de moradia fora da Cracolândia, porém, era um local para onde procurava dirigir-se o mínimo possivel, por ter problemas de relacionamento com seus parentes. Os problemas de relacionamento também estavam presentes na casa de Mariano e ambos declaravam serem estes problemas decorrentes do uso de crack.

Tanto para Carazinho quanto para Mariano, ambos na faixa dos 40 anos de idade, estar na Cracolândia era sua maneira de 
livrar-se da desaprovação familiar ao uso, possivelmente eles não conseguissem controlar os efeitos do crack a ponto de poder utilizá-lo próximo ao convivio familiar. Mas não era apenas isto o que os afastava deste convivio. Como observou Howard Becker, para poder desfrutar dos efeitos prazerosos da maconha, se faz necessária a companhia de outros maconheiros e distância de não usuários, capazes de obrigar o maconheiro a dispender um grande esforço em disfarçar os efeitos da droga ao invés de aproveitá-los. Vimos como os efeitos prazerosos do crack dependem da "sintonia" entre usuários e de como isto só é possível na companhia destes. Além disto, o uso do crack pode prolongar-se por dias ininterruptos, dificultando ainda mais sua fruição nas proximidades da companhia familiar e aproximando, portanto, os usuários uns dos outros. Para fumar crack, é melhor estar na companhia de outros craqueiros. Para estar na companhia de outros craqueiros e não comprometer sua "sintonia" é necessário fumar crack. A prática da "treta" possibilita a todos o fruir da pedra, democratizando seu acesso. Uma "biqueira" a céu aberto, ou mesmo a Cracolândia são locais onde se pode estar livre da companhia julgadora de não usuários, sejam eles familiares, amigos, colegas de trabalho ou faculdade, e, ao mesmo tempo, estar na companhia de outros usuários com quem se pode viver a "sintonia"; assim como das fontes de fornecimento e circulação da pedra através da "treta". Situação similar pôde ser observada por Christiane F. a partir do final dos anos 1980 do século passado, no parque da Platzspitz em Zurique.

No final da década de 1980, o parque da Platzspitz se tornou o ponto de encontro de viciados expulsos de outros lugares. Por muito tempo tolerados pela polícia e pelos políticos, os drogados vinham de toda Suíça e do exterior. A maioria vivia na pobreza e financiava o vício com roubos ou prostituição. Na margem dos rios, várias pequenas comunidades foram construídas com caixas e coisas jogadas fora, pois a maior parte dos viciados não contava com abrigos na época. As habitações provisórias 
eram regularmente derrubadas pela polícia, mas as autoridades começaram a temer que o Platzspitz acabasse se tornando uma área marginal livre. (FELSCHERINOW; VUKOVIC, 2014, p. 98)

A Suiça também viveu seus tempos de Operação Dor e Sofrimento $^{84}$ e aparentemente, como descrito acima, o uso da heroína também produz seus guetos, ou praças de uso como a Platzspitz. Até mesmo os barracos estão presentes para garantir o mínimo de proteção contra o olhar, além do sono reparador após um possível longo período de uso. Porém, nos interessa aqui pensar sobre as razões de surgirem locais de uso coletivo $^{85}$ de certas drogas, como a Cracolândia paulistana, a Platzspitz de Zurique ou os "espaços legalize” de Salvador/BA.

'Legalize' é uma categoria nativa, possivelmente soteropolitana, que se refere a certo contexto social e simbólico, situado no tempo e espaço, onde o consumo público de maconha é tolerado socialmente. Isso não significa que este não seja ilícito, mas sim que os grupos sociais dispostos entre pares que dividem o espaço delimitado podem consumir, ou não a erva ilegal sem maiores preocupações com os controles formais e repressores. Em termos gerais, o que caracterizaria um espaço urbano 'legalize' seria um estado de liberdade relativa, no tempo e espaço, para o uso de maconha e/ou outras drogas ilícitas em um dado território geográfico urbano público ou privado. (SANTOS, 2013)

Norman Zinberg (1984) também chamou a atenção para ocasiões especiais com o envolvimento de multidões no uso de drogas como bebedores de cerveja em jogos esportivos, maconheiros em concertos de rock e mesmo o uso de vinho e coquetéis em refeições e finais de tarde, de tal modo que:

84 Violenta ação repressiva realizada na Cracolândia, no início de 2012, pelas administrações Alckmin e Kassab frente aos governos municipal e estadual, respectivamente.

85 Não é a droga que produz estes locais de uso coletivo. 
[...] apesar de suas diferenças culturais, tornaram-se tão generalizadamente aceitos que pouca ou nenhuma restrição legal é aplicada mesmo que tal uso quebre a lei. Por exemplo, um policial pode dizer a adolescentes bebendo cerveja em um concerto a céu aberto para 'pararem com isso', mas ele raramente irá prendê-los; e em muitos estados americanos a reação policial poderá ser similar mesmo se a droga for maconha. (ZINBERG, 1984, p. 6, tradução nossa)

Com o intuito de permanecerem desviantes secretos, usuários de crack, heroina e também de maconha procuram locais onde o uso da droga não interfira em seu relacionamento com não usuários, cuja aceitação eles valorizem e que lhes possam impingir sanções morais, sentimentais, físicas ou financeiras. Em companhia de outros usuários de drogas e em locais não frequentados pelos não usuários por eles valorizados conseguem permanecer impunes. Há, portanto, uma disposição à aproximação cada vez maior com o grupo de usuários das Cracolândias, Platzspitz e dos "espaços legalize" e uma disposição contrária às interações com não usuários, principalmente os mais próximos, ou cujo julgamento seja mais valorizado. A presença de usuários "bem sucedidos", como visto anteriormente no caso de Antônio, ajuda a promover uma concepção mais positiva sobre a droga e sobre a possibilidade de seu consumo com sucesso ou por prazer. No caso de Esmeralda, o fato dela encontrar-se em situação de rua desde a infância e ser ainda uma jovem adolescente, a expôs às concepções da sociedade mais ampla sobre o uso do crack de um modo ampliado pelas experiências drásticas de uso existentes em seu universo de rua. Ela só pôde vencer tais interdições com o auxílio paciente de sua "parça" mais próxima.

Existem dificuldades de ordens diversas para se usar drogas na presença ou na proximidade de pessoas valorizadas pelo usuário. Ser descoberto é correr o risco da desqualificação decorrente do estigma criado pelo pânico moral em torno do uso e 
do usuário de drogas ilícitas. É correr o risco de sofrer sanções legais que podem chegar até a prisão como foi o caso da Christiane F. adulta, de Mariano, de Carazinho e de Esmeralda. Ser um desviante puro (BECKER, 2008), ou aquele que demonstra possuir um comportamento infrator e é percebido como desviante, enfim, "ser do crack" expõe esta pessoa à grande probabilidade de ser taxada como irresponsável, descontrolada ou mesmo louca. Mariano, em uma entrevista profunda, nos informou a respeito de seu relacionamento problemático com a avó e sobre uma espécie de profecia feita por seu avô, ainda quando ele era menino e morador de uma cidade do sertão nordestino. Seu avô disse que ele "não daria em nada", ou seja, não seria nada na vida e as prisões de Mariano por roubo de veículo e outros crimes vieram confirmar a maldição do avô perante toda família. Neste sentido, o uso do crack foi mais um capítulo em uma história marcada pela progressiva retirada de afeto por parte de seus familiares, até colocá-lo em situação semelhante à de rua, se considerarmos seus longos períodos nas calçadas da Cracolândia. Assim sendo, estar na Platzspitz ou na Cracolândia é uma forma de ostracismo impulsionada pelas concepções e sanções advindas do proibicionismo com relação às drogas tornadas ilícitas e a sua expressão ideológica, o pânico moral. A carreira do usuário nestes casos se torna uma carreira de progressiva exclusão da sociedade abrangente e de inclusão em um grupo desviante organizado, com todo o impacto que isto tem sobre a concepção da pessoa sobre si mesma. Ela passa a assumir que "sou da marginália, sou do crack", adotando uma identidade desviante, advinda de um sentimento de destino comum aos usuários de drogas. Com todos sujeitos às mesmas leis que os criminalizam, aos mesmos estigmas e compartilhando um entendimento comum sobre o mundo ao redor e suas ameaças e possibilidades, uma cultura desviante pode surgir. Define-se assim, um cotidiano, um modo de vida, ou, como muito bem apontou o usuário de heroína e escritor W. 
Burroughs: "O barato junky é ter de viver sob condições junkies". (BURROUGHS, 2013) A esta vida junkie é perfeitamente possível ter-se acesso na Cracolândia, na Platzspitz e de certa forma nos "espaços legalize". Digo de certa forma porque o estigma em torno da maconha atualmente, no Brasil, nos parece algo distinto do vivenciado por Becker nos EUA do início dos anos 1960 do século passado, portanto, a necessidade da manipulação dos sintomas do uso da maconha pode ser menor em relação ao crack. Mas isso não significa de modo algum, que o usuário de crack fique mais "antissocial" que o usuário de maconha ou de cerveja. Nossa experiência de campo comprovou como o ambiente da "biqueira", ou mesmo da Cracolândia pode ser extremamente cordial na ausência de maiores conflitos relacionados à distribuição ou aquisições de crack. Estas divisões são feitas de modo cortês na imensa maioria das vezes e entre pessoas que se conhecem há certo tempo por serem frequentadoras do mesmo espaço. Sabemos que, para Becker, garantir o sigilo é condição para o avanço bem-sucedido na carreira de usuário de maconha, seja ele mantido pela competente administração dos sintomas ou pelo afastamento com relação aos "caretas". A tendência a isolar-se da sociedade mais ampla e socializar-se preferencialmente com outros maconheiros é proporcional à capacidade de administração destes sintomas e ao desejo de consumir regularmente a agora, tão desejada e prazerosa maconha.

A menos que descubra um método para superar essa dificuldade, a pessoa só pode avançar para o uso regular quando a relação que impede o consumo é rompida. As pessoas não costumam deixar seus lares e suas famílias para fumar maconha regularmente. Mas se o fazem, não importa por que razão, o uso regular, até então vetado, torna-se uma possibilidade. Usuários regulares confirmados muitas vezes consideram seriamente o efeito do estabelecimento de novas relações sociais com não usuários sobre seu uso de droga. (BECKER, 2008, p. 78) 
Usar crack e conviver com parentes é mais que uma questão de manejo de sintomas, é também uma questão de manejo de um agenciador físico (FIORE, 2013), a fumaça. Tal qual o usuário de maconha, o craqueiro se vê às voltas com as dificuldades de usar sua droga sem ser denunciado pelo aroma característico da sublimação da pedra de crack, pela luminosidade emanada do "Bic", pelos dedos enegrecidos pelo contato com a cinza de cigarros, pela fumaça e luminosidade do próprio cigarro, pelo cheiro a impregnar as vestimentas e cabelos, pelos lábios ressecados e às vezes rachados, pela voz grave, pela baba branca a ocupar o espaço das extremidades dos lábios e enfim, pelo desejo de estar entre iguais e partilhar da "sintonia".

Para não ser necessário romper as relações com não usuários seria preciso aprender a controlar os efeitos da droga e prosseguir como desviante secreto. "Os imperativos morais básicos que operam aqui são os que exigem que o indivíduo seja responsável por seu próprio bem-estar e capaz de controlar seu comportamento racionalmente". (BECKER, 2008, p. 82) Estes imperativos, relativos aos usuários de maconha capazes de controlar os sintomas provenientes do uso e abastecer-se competentemente da droga, não corresponde ao estereótipo do usuário de drogas irresponsável e despreocupado com sua performance. Como podemos observar neste trecho de um artigo sobre o consumo de maconha:

E o uso da Cannabis passa a ser um ato rotineiro e, aos poucos, essas sensações agradáveis começam a mudar: o relaxamento vai virando preguiça, a calma vai transformando-se em lassidão, a melhora do humor e do otimismo começa a virar postergação, a necessidade de fazer coisas que não se gosta de fazer, começa-se a deixar para mais tarde. "Depois eu faço"[...], 'Amanhã eu faço[...]', o aumento das ideias criativas vão se tornando uma criatividade apenas teórica ‘Tudo bem...'. (KWITKO, 2014)

Para o usuário não condenar a si mesmo negativamente como desviante é preciso que desenvolva uma visão alternativa, 
da qual fazem parte racionalizações e justificativas diferenciadas das ideias convencionais presentes na sociedade ampliada, sobre a suposta escravidão às drogas. Isto é possivel pela interação em um segmento não convencional da sociedade, possuidor de um repertório de respostas às objeções sociais e mesmo de acusações aos modos de ser da sociedade, como a acusação de cinismo àqueles que se entregam a práticas nocivas como o consumo do álcool e certos alimentos prejudiciais à saúde. Esquematizamos na figura abaixo, como os estereótipos convencionais atribuídos ao maconheiro como sua pretensa irresponsabilidade, falta de controle e mesmo loucura vão sendo combatidos por racionalizações e justificativas provenientes de um repertório de respostas aprendidas no grupo não convencional de maconheiros experientes.

Figura 29 - Moralidade e Racionalizações

Uso de maconha e controle social - Moralidade

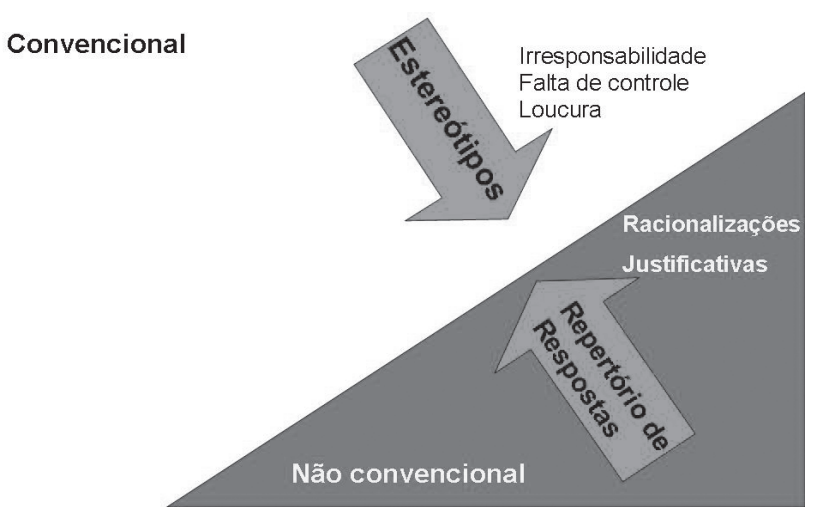

Fonte: Coleção particular do autor.

Infelizmente, falta aos usuários de crack, nossos interlocutores, a possibilidade de construir uma visão positiva a respeito deles mesmos e de sua prática de uso, possivelmente devido 
a avassaladora ideologia do proibicionismo, ou pânico moral em torno do crack. Pelo contrário, eles têm, geralmente, deles mesmos e dos pares à sua volta a visão mais negativa possivel, muito próxima à visão do "Zé Povinho" sobre eles. Fica, portanto, uma situação aparentemente dúbia, os craqueiros desprezam tanto o não usuário preconceituoso quanto o usuário vítima de preconceito, embora em nossa convivência com eles alguns sinais de saída deste estado de "coisas" possam ser vislumbrados.

A primeira delas nos veio pelo depoimento de Corintiano, primo de Mariano e residente na região da Luz há pelo menos uma década. Casado com uma usuária, ele aparenta possuir em torno de 35 anos. Começamos uma conversa em meio à comemoração da festa junina do ano de 2013, realizada na rua Dino Bueno. Primeiramente, conversamos no meio da rua para em seguida, nos dirigimos à calçada para que Corintiano pudesse fazer uso das pedras em seu poder com o mínimo de "radiação". Durante nossa conversa, que durou umas 2 horas, ele foi abordado por diversos usuários pedindo para serem "favorecidos" e propondo as mais diversas "tretas". Corintiano se irritava com tal assédio, mas também participava da "treta" quando ela se mostrava vantajosa. Ao me oferecer para compra, ainda no meio da rua, um interessante cachimbo feito de lâmpada, ele começou a tecer algumas considerações sobre a visão negativa que os não usuários possuíam deles, os craqueiros. "Eles acham que nós somos lixo, né? Se eles vêm um cara caído na rua, ninguém faz nada. Se eu vir um cara caído na rua, eu vou ajudar, não vou tratar ele como lixo. [...] Nós somos a nova Jerusalém."

Corintiano possui certa visão positiva e mesmo superior dele com relação ao "Zé Povinho", pois ele se vê como alguém altruísta e solidário. Quando lhe peço de volta um cachimbo meu, ele me declara: "Eu ia te devolver, porque eu sou homem." Portanto, ser alguém de índole honesta é um valor entre 
os usuários de crack tanto quanto na sociedade abrangente, ao menos nas classes trabalhadora e média ao corresponder em sua conduta com este valor é também fonte de orgulho. Ser honesto também foi uma característica motivo de orgulho para outro usuário, Mariano. Ao conversarmos a respeito de "gente que pilantrava" e que era punida pelos irmãos, Mariano fez questão de nos contar a respeito de casos em que objetos de valor the foram confiados e da maneira correta como ele se comportou. Portanto, nossos interlocutores são perfeitamente capazes de ter também uma visão positiva a respeito de si próprios como seguidores ordeiros da disciplina imposta pelos irmãos e também como pessoas bondosas, altruístas, enfim uma "nova Jerusalém".

Pude observar outras formas de autoimagem positiva nas figuras dos interlocutores Dobem e Zezé, ${ }^{86}$ o primeiro orgulhoso por ser "malandro" e por estar "na responsa" garantindo o "fluxo" na "biqueira". O segundo se sente orgulhoso por deixar seu barraco arrumado, o melhor da "biqueira" a céu aberto e por "brisar na libido", por ter namorada na "biqueira", pela atração que exerce sobre algumas mulheres jovens e bonitas e principalmente, por não ser um "parasita" ou um "nóia", como podemos observar no diálogo abaixo:

Zezé - Olha, desde a hora que cheguei, me alimentei, conversei, arrumei um pouco o barraco [...] Aquilo que havia requisitado que ele estava tomando da mesa, que ele colocou, mais de cinco minutos depois, eu vou fumar. Isso é uma grande diferença entre usuário consciente [...]

Newman interrompe - 'Nóia' sem noção.

Zezé prossegue o raciocínio - [...] E o dependente químico. Zezé - Eu sou dependente, mas num grau diferente. Eu consigo, por exemplo, deixar de fumar e ir fazer uma 'caminhada', fazer outra coisa e depois buscar a droga. Isto porque eu estou virado somente um dia, se tivesse virado dois dias, quando eu cheguei, eu teria que mandar, por quê?

86 Mais à frente descreveremos melhor o usuário Zezé. 
Zezé diferencia o usuário consciente do dependente químico. O primeiro é capaz de dominar sua vontade e cumprir seus afazeres. No decorrer deste livro veremos maiores implicações destas declarações de Zezé. Em Salvador/BA, a antropóloga Luana Malheiros observou algo semelhante com o distanciamento entre "usuários" e "sacizeiros":

O 'sacizeiro' seria o consumidor iniciante, aquele que não consegue regular o uso devido ao pouco tempo de contato com a substância, segundo a classificação de Becker. Seria o indivíduo que tem um uso compulsivo e disfuncional de crack, sem emprego fixo e cuja atividade de trabalho varia de pequenos furtos à mendicância, o que torna a sua estrutura de vida precária. (MALHEIROS, 2012, p. 85)

Seguindo no esquema de Becker, se superar bem, em sua carreira de usuário de maconha, os desafios quanto ao fornecimento da droga, ao sigilo quanto a seu uso e livrar-se dos impedimentos morais a constrangê-lo, o maconheiro poderá finalmente se tornar um usuário controlado. Isto, de modo algum, irá leva-lo ao comportamento estereotipado de estar usando o tempo todo, muito pelo contrário [...] "Seu uso é planejado; considera-o apropriado em certas ocasiões, não em outras". (BECKER, 2008, p. 84) Ele assegura para si mesmo possuir o controle sobre seu uso da droga e isto funciona como símbolo dele desempenhar uma prática inócua. Portanto, não é escravo porque planeja e segue seu plano quanto à quantidade, frequência e oportunidade, com períodos sem o uso da substância psicoativa. Ao reorganizar suas noções morais pode vir a adquirir a concepção de que os valores convencionais sobre drogas não se aplicam ao seu caso, de um uso não excessivo, mas regular. Além de serem sem maiores prejuízos à sua vida, pelo contrário, ele é possibilitador de um fruir cotidiano mais prazeroso e em melhor companhia. Mesmo assim, com o uso regular, questões morais novamente podem reaparecer e o convencimento anterior pode precisar ser reatualizado por testes 
como o abandono do uso por algum tempo, para certificar-se não ser seu padrão corresponde aos da mitologia popular sobre o viciado.

Figura 30 - Uso controlado

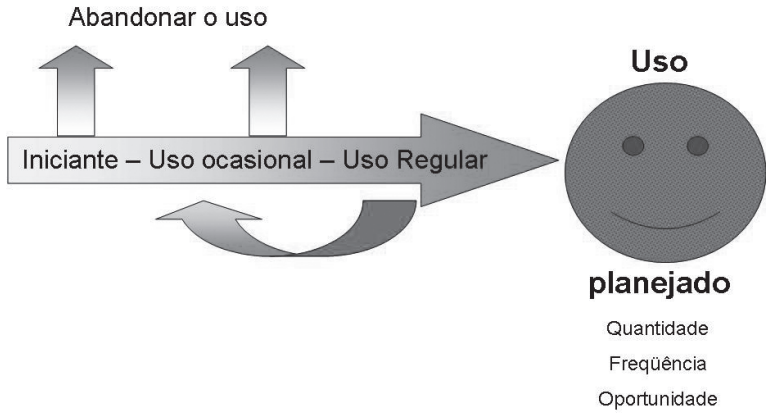

Fonte: Coleção particular do autor.

Um usuário regular pode, portanto, retornar ao uso ocasional e mesmo abandonar o hábito por algum tempo para certificar-se não ser "escravo da droga" como grita o convencionalismo. Sua visão a respeito de seu comportamento como usuário de maconha irá paulatinamente se aproximando da visão compartilhada entre os insiders. Isto se dá na medida de seu distanciamento do modo convencional de considerar esta questão, a dos agora, outsiders. "Em suma, uma pessoa se sentirá livre para usar maconha à medida que passe a considerar as concepções convencionais sobre ela como as ideias mal fundamentadas de outsiders e as substitua pela visão inside que adquiriu por meio de sua experiência com a droga na companhia de outros usuários”.(BECKER, 2008, p. 87)

\section{Além da dependência física e psicológica, a dependência social}

O crack possui uma diferença fundamental com relação à maconha dentro da perspectiva trabalhada por Becker. Ele consi- 
dera a maconha uma droga incapaz de produzir um uso problemático; por isso, seu uso prolongado ocorre na medida do prazer proporcionado por ela. Assim, o maconheiro só irá tornar-se usuário perene caso consiga vencer uma série de etapas em sua carreira e não por ter se tornado "dependente". No caso do crack há o complicador da fissura, inexistente ou pouco presente no uso da maconha. Assim sendo, o uso do crack se mantém, certamente devido ao prazer por ele gerado, mas, também pode prolongar-se ao longo de tentativas sucessivas de se livrar da fissura. Convém-nos ressaltar neste momento a profunda presença de um componente social na manutenção do uso, mesmo em face de consequências deletérias. Ou seja, o prazer por encontrar-se na presença do grupo de usuários, o status alcançado e o prestígio entre os pares, assim como o fascínio pelo ritual de uso são aspectos a serem observados no intuito de considerarmos ao máximo as conexões vividas pelo usuário de crack, passiveis de gerar prazer e mantê-lo em seu hábito. Igualmente, deve-se levar em conta a dificuldade de abandonar esta rotina por ela ter proporcionado um modo de vida no interior do grupo de usuários. No diálogo abaixo, com um ex-usuário de crack da região da Cracolândia paulistana, que atualmente trabalha como orientador socioeducativo com esta mesma população, podemos observar um pouco desta dependência dos vínculos estabelecidos no uso da droga, assim como de certos rituais:

Antônio - Outra, a questão da dependência química que eu achei que era um fator preponderante, não é. É o fator menos importante na oficina. O que eu achei interessante, a partir de um cutucão da minha esposa foi começar a falar nisso. Para desmistificar. O povo pensa: 'É morador em situação de rua, o problema é dependência química'. E não é.

Ygor - E porque que você acha isso?

Antônio - Porque o povo acha isso? 
Ygor - Não, porque você acha que o problema não é a dependência quimica?

Antônio - É um problema social, cara. Tem um recorte de classe aí, também. O problema do morador em situação de rua é o quê? Morador em situação de rua vai existir sempre no nosso sistema.

Ygor - O problema não é a pedra. Qual o problema?

Antônio - Pra ele, pode ser um refúgio, pode ser uma desculpa, pode ser uma alternativa. Às vezes, ele pode estar entediado, mas não é este o fator de ele estar na rua. Briga com a família, desilusão amorosa, migração, baixa escolaridade, desemprego, baixa qualificação, ou não qualificação, não tem qualificação nenhuma. E pra você? O que que você acha?

Ygor - Eu não sei. Eu conversei com as pessoas e todo mundo tem uma história triste para contar. 'Ah, minha família, minha mãe', história de corno, entendeu? Imagina ficar na rua sem fumar pedra?

Antônio - Imagina ficar na rua sem beber pinga!

Ygor - O cara vai fazer o corre atrás da pedra e preenche o tempo, entendeu?

Antônio - Dá motivação. Não, eu falei para você, né? Eu lembro quando eu fui fazer. No meu último tratamento. Foi um tratamento um pouco mais técnico que mexeu com a minha parte psicológica. Nunca havia olhado para isso. Eu comecei a perceber através de terapia que as relações que eu tinha através de droga, a parceria, o 'corre', como preparar o negócio. Tudo isso tinha tanta força quanto o crack.

Ygor - Claro. O ritual é sensacional.

Antônio - Porque eu falo para você. Sandra (esposa), eu não lembro da 'brisa' faz muito tempo, mas eu lembro disso e parece que me dá prazer de lembrar. Quando eu subia o escadão de Santos pra buscar droga, eu lembro. Quando eu ficava pra trocar uma ideia com os caras, eu lembro. Quando eu ia junto com uma mina fumar droga, eu lembro.

Ygor - Do 'corre', da 'sintonia'[...]

Antônio - Tudo, maravilha. Porra cara! O livro 'Prevenção da recaida' fala dessas relações que se tem com a droga, que tem que colocar as pessoas em outras relações. Ba- 
seado também em Narcóticos Anônimos (NA), ${ }^{87}$ 'Lugares, hábitos e pessoas'.

Ygor - Só por hoje.

Como brilhantemente observou Timothy Leary: “O usuário é viciado não apenas na droga, mas também no ritual da procura. Em vários casos, obtê-la é a absorvente aventura de um dia inteiro para pessoas que, de outra forma, estariam entediadas ou frustradas com a vida". (LEARY, 1999, p. 432)

Antônio, nosso interlocutor, abre com suas observações uma nova perspectiva na análise do abuso de drogas e particularmente, do crack para além das observações de Becker sobre a importância das interações pessoais no aprendizado das técnicas de uso, percepção dos efeitos e sua significação como prazerosos. Todo este suporte grupal possibilita o uso bem sucedido da maconha por prazer é profundamente importante e sem ele, segundo o modelo de Becker, este uso prazeroso seria em muito dificultado. Porém, outra escala de importância do grupo, ou grupos de usuários com quem o craqueiro terá contato em sua carreira, surge ao levarmos em conta o depoimento de Antônio e nossas observações de campo.

$\mathrm{Na}$ oficina de futebol oferecida por Antônio como seu trabalho socioeducativo ligado a Centros de Convivência conveniados com a Prefeitura Municipal de São Paulo, o uso do crack não lhe aparece como o determinante da situação de rua, na qual os participantes da oficina se encontram. A chamada "dependência química", ou dependência de substância como consta do Diagnostic and Statistical Manual of Mental Disorders (DSM-IV) ${ }^{88}$ (KAY; TASMAN; LIEBERMAN, 2002) não é o dado mais significativo dos participantes das oficinas de futebol e sequer dos moradores de rua, segundo este educa-

87 Narcóticos Anônimos

88 A última versão do DSM, de $n^{\circ}$. V, traz o conceito de transtorno por uso de substância. 
dor, ele mesmo ex-usuário de crack e ex-morador de rua na região da Cracolândia paulistana. Esta opinião é compartilhada por sua esposa, também ela com larga experiência no trabalho com esta população e na mesma região central da cidade. Em nossas observações de campo, participamos de diversas rodas de crack e descrevo abaixo, um dos barracos por nós frequentado e as motivações de Zezé, seu dono, para encontrar-se em situação de rua fazendo uso cotidiano de crack. O trecho abaixo foi retirado do caderno de campo de fevereiro de 2013

Um pequeno móvel aparentando ser um armário de banheiro com espelho e contando com uns $40 \times 30 \mathrm{~cm}$ encontrava-se no chão, mais ou menos no meio do barraco. Era o único item de mobiliário e estava destinado ao preparo do crack e ao depósito das pedras disponiveis para uso dando também suporte aos aparelhos, ferramentas e demais componentes da parafernália de usuário. Às vezes, este pequeno armário era aberto, mas não se costumava guardar muita coisa em seu interior, preferindo-se manter os objetos à mostra. Duas revistas eróticas circulavam pelo barraco, servindo como suporte para o preparo das misturas de crack com cinza, antes de serem colocadas no cachimbo para uso. Tanto homens quanto mulheres usavam as revistas como base. O dono do barraco era um carioca, entre 45 e 50 anos de idade, ele nos declarou ser artista plástico, produtor de peças que serviam de base para confecção dos moldes utilizados na produção em série de estatuetas. Também fez fontes de água em pousadas e diz ter tido empresa, 'maquinário' e funcionários. Tentou suicídio duas vezes. Cometeu o assassinato de seu ex-cunhado após este estuprar sua irmã, engravidá-la e fugir para a região nordeste do país. Aos 12 anos, saiu no encalço do estuprador para encontrá-lo; aprendeu a viver na rua até poder efetuar sua execução com uma pedrada na cabeça. A primeira tentativa de suicidio veio após ser agredido pelo sobrinho, filho do estuprador por ele assassinado. Este sobrinho foi motivado pelo conhecimento das condições da morte do pai, estuprador da própria mãe. A segunda tentativa de suicídio veio após retornar de uma das viagens para confecção e instalação de fontes para 
piscina em pousadas. Ele costumava hospedar-se nestas pousadas enquanto realizava o serviço, uma condição para ele muito agradável. Ao retornar de uma destas viagens a trabalho encontrou sua esposa vivendo com outro homem e seu negócio, com 'maquinário', galpão e funcionários desfeito e vendido pela esposa traidora em conluio com o irmão dele. Pulou em tentativa de suicídio de altura de 10 metros tendo de passar vários meses internado. Ao sair não recebeu apoio familiar algum e entrou em depressão. Chegando à rua foi trabalhar em reciclagem. 'Desisti e aqui encontrei um meio de coexistir'.

Todos na rua têm seu "vulgo", aqui usaremos o vulgo do vulgo para nos referir novamente ao nosso interlocutor cuja história foi brevemente resumida acima e o chamamos de Zezé. Ele fala de modo calmo, educado e extremamente articulado; não possui gestos bruscos ou violentos, fala sobre si e sobre "quem fuma crack" e orgulha-se de ter dado vulgo a muita gente. Como meu nome é de origem russa, Zezé, um dia, propôs vodca como meu vulgo.

Vejamos, portanto, a história de Zezé juntamente com as considerações de Antônio sobre o morador de rua. Como vimos, Zezé aprendeu a viver na rua aos 12 anos de idade em uma situação particularmente traumática e fora de sua cidade. Havia viajado para localizar e assassinar o estuprador de sua irmã e pai de seu sobrinho. Consumado o assassinato, uma série de infortúnios o levou a duas tentativas de suicídio, tendo a segunda tentativa o deixado particularmente vulnerável após longa internação. Abandonado pela família e com os negócios destruídos pela esposa infiel encontrou na vida na rua, organizada em torno do consumo do crack, um local para "coexistir". Portanto, o uso da pedra de crack proporcionou um ambiente social propício a acolher Zezé. Após duas tentativas de suicídio e não possuindo mais sua fonte de sustento e tão pouco apoio familiar, mesmo porque com o fato dele ser o assassino do cunhado, pai de seu sobrinho, certas portas se fecharam na família. Elas se tornaram ainda mais cerradas pela traição 
cometida pela esposa e pela perda das fontes de renda. Assim sendo, o cotidiano fornecido pelo uso em grupo do crack preenche o espaço diário de atividades com a busca por meios para sustentar o consumo da droga, as relações afetuosas com mulheres, conforme visto em momento anterior deste trabalho, no "corre", na "treta", na manutenção a todo instante do barraco, em conversas e numa grande gama de atividades condizentes com a situação de rua. Se quisermos usar jargões correntes da psiquiatria, como o de dependência química, ou dependência de substância, poderíamos também sugerir a existência de uma dependência social de todas estas relações, vínculos e práticas proporcionadas pelo uso do crack.

Assim sendo, as observações de Antônio sobre suas recordações saudosas de muitas das atividades concernentes ao uso de crack no centro de São Paulo e na cidade litorânea de Santos, tomam outra feição. Ao afirmar serem as "relações" advindas do uso do crack o elo mais forte com o uso, ainda remanescente após uma década de abstinência, ele nos revela a força das diversas conexões estabelecidas a partir da droga e nos leva a pensar para muito além de seus estritos efeitos: "a parceria, o 'corre', como preparar o negócio. Tudo isso tinha tanta força quanto o crack". Dependência social vinculada ao uso de drogas e particularmente ao uso do crack está ligada a importância do ritual na vida humana. Ao acostumar-se a um ritual, o usuário tende a desejar repeti-lo, principalmente ao se tratar de um ritual prazeroso associado a um consumo recreativo de drogas, também ele em si proporcionador de prazer. Devemos dar a devida atenção ao fato de que "preparar o negócio" dá prazer.

Como vimos nas observações de Timothy Leary a respeito de como o esforço desprendido para se obter a droga faz parte do uso, usar uma droga é também envolver-se no mundo das drogas, com pessoas usuárias e traficantes de drogas; é partilhar de suas preocupações, de seu cotidiano. Isto claramente 
Jamais fomos zumbis

deixa lembranças e faz parte da totalidade do uso, como muito bem observou Antônio:

Antônio - Eu não lembro da 'brisa' faz muito tempo, mas eu lembro disso e parece que me dá prazer de lembrar. Quando eu subia o escadão de Santos pra buscar droga, eu lembro. Quando eu ficava pra trocar uma ideia com os caras, eu lembro. Quando eu ia junto com uma mina fumar droga, eu lembro.

Assim, podemos realmente separar o prazer das amizades, da companhia, dos relacionamentos amorosos, dos flertes entre usuários tantas vezes por nós testemunhados nos locais de uso, dos efeitos do crack? A recorrência no uso teria muito a ver com certa "fissura da rua" (GREGIS, 2002), fissura, neste sentido que vai muito além de se procurar "evitar o desconforto da privação”. (KAY; TASMAN; LIEBERMAN, 2002) Se analisarmos as definições consagradas de dependência química veremos como a dependência social preenche uma lacuna de interpretação do uso de drogas e abre novas possibilidades para sua compreensão.

Segundo definição da Organização Mundial da Saúde (OMS) a dependência química é:

[...] [o] estado psíquico e algumas vezes físico resultante da interação entre um organismo vivo e uma substância, caracterizado por modificações de comportamento e outras reações que sempre incluem o impulso a utilizar a substância de modo contínuo ou periódico com a finalidade de experimentar seus efeitos psíquicos e, algumas vezes, de evitar o desconforto da privação. (FIDALGO; NETO; SILVEIRA, 2012, p. 2)

Pela perspectiva adotada até agora, fica claro como o encontro entre o organismo vivo humano e a substância dá-se em um contexto social capaz de conferir propósito a este uso. Todos os outros fatores levantados acima, como o aprendizado que torna possivel sentir os efeitos e lhes dar significação positiva; 
o grupo de pares que proporciona um repertório de justificativas para o uso e meios para obtenção da droga. Somados são a um grupo onde o uso não seja mal visto e dentro do qual se possa gozar dos efeitos da droga em companhia de outros usuários.

Interessa-nos ressaltar neste momento, dentro da definição de dependência química "o impulso a utilizar a substância de modo contínuo ou periódico". (FIDALGO; NETO; SILVEIRA, 2012, p. 2) Este impulso, por outros chamado de compulsão, seria o dado propriamente psicológico da dependência segundo o discurso estabelecido a respeito da dependência de substância. A dependência teria um aspecto físico e outro psicológico. $\mathrm{O}$ contexto social ficaria restrito, por exemplo, aos itens $\mathrm{V}$ e VI da DSM-IV, como o tempo "gasto em atividades necessárias para obtenção da substância" e na "utilização da substância ou na recuperação de seus efeitos", assim como no fato de que também "importantes atividades sociais, ocupacionais ou recreativas são abandonadas ou reduzidas devido ao uso de substâncias". (KAY; TASMAN; LIEBERMAN, 2002, p. 190)

Portanto, como vimos acima, o contexto social é relegado pela DSM-IV às atividades de obtenção, uso e "recuperação" dos efeitos da droga. ${ }^{89}$ Contudo, vimos como o ritual de uso e o companheirismo entre os usuários são fundamentais para compreender a atração exercida pelo contexto social sobre os usuários de crack. Este contexto também é atraente por fornecer um meio seguro para se usar a droga e se evitar as sanções das pessoas valorizadas pelos usuários de crack. É um porto seguro e de certa forma aconchegante de pares com interesses em comum em torno da droga, com uma visão, se não positiva, ao menos tolerante e dotada de valores com os quais se podem identificar e obter a satisfação e valorização negadas pela sociedade abrangente e contaminada pela ideologia do proibicionismo, ou pânico moral.

89 Pouco se alterará no DSM-V esta visão restrita do contexto social. 


\section{Norman E. Zinberg e a importância do setting no uso de drogas}

Duas décadas após a publicação do trabalho seminal de Howard Becker, Norman E. Zinberg publica uma pesquisa absolutamente fundamental para a compreensão da questão do uso de drogas sob uma perspectiva social. Drug, set, and setting: the basis for controlled intoxicant use foi publicado no ano de 1984, pela Yale University Press. A obra foi baseada em investigação realizada após mais de 20 anos de experiência clínica do autor, médico e professor de psiquiatria clínica na Universidade de Harvard. Ele procurou saber como e porque muitos usuários, frente a outros que faziam uso descontrolado, conseguiram conquistar e manter o controle sobre o uso de certas drogas. O setting, ou contexto de uso, passou a ganhar importância de certa forma por acaso, ao se perceber que a atitude dos médicos influenciava o efeito que as drogas por eles prescritas tinham nos seus pacientes. Em 1968, Zinberg pôde, através de uma bolsa, estudar o sistema britânico de terapia de manutenção de heroína e encontrar lá, dois tipos de adictos, ambos diferentes do americano. O primeiro, que funcionava adequadamente até mesmo com sucesso e o segundo, ainda mais debilitado que o viciado norte americano, porém, como o alcoólatra americano, não era causa de apreensão, criminalidade ou histeria pública. Estas diferenças entre países puderam aos poucos ser atribuídas aos diferentes settings sociais e às diferentes atitudes sociais e legais com relação ao uso de drogas e aos usuários. Na Inglaterra, o uso de heroína não era crime e os adictos podiam ser legalmente supridos, estavam livres das restrições legais e de boa parte do estigma. Isso lhes dava a possibilidade de escolher entre aceitar o uso de drogas como fato e manter suas atividades rotineiras, ou verem-se como anormais e adotarem um estilo de vida destrutivo. Tornava-se claro que não seria mais possivel, para entender a experiência com a droga, limitar-se a farmacologia (drug) e a personalidade do usuário (set), mas 
também deveria-se atentar ao ambiente (setting) físico e social em que o uso ocorre.

Ao se debruçar sobre o problema do abuso de drogas entre alistados no Vietnam, Zinberg pôde perceber que o uso pesado de heroina entre as tropas, assim como outras atitudes, estava ligado à atração exercida por atividades que apagassem o mundo externo. O setting proporcionado pela guerra não permitia que rituais e sanções sociais de controle tivessem chance de se desenvolver, isto dificultava muito o uso controlado. Porém, assim que os abusadores foram retirados do ambiente nocivo, o abuso virtualmente cessou. Ao prosseguir suas pesquisas com usuários de heroína, Zinberg percebeu a existência de numerosos padrões de uso, como usuários de final de semana e mesmo usuários ocasionais de longa duração.

Era amplamente difundido no século XX, a ideia de ser a heroina comumente procurada por pessoas com profunda desordem de personalidade e que para elas, a abstinência total se tornara a única alternativa. Estudos dos anos 1960 do século passado igualavam uso a abuso e raramente consideravam o uso moderado ou ocasional como um padrão viável. O uso não abusivo era tratado como um estágio de transição breve rumo à abstinência, ou, mais comumente, ao uso compulsivo. Os pesquisadores da época e em grande medida até os dias de hoje, procuravam primeiro determinar os potenciais efeitos danosos das drogas ilícitas para então, estudar as desordens de personalidade resultantes do uso destas substâncias. Desordens que eram, ironicamente, consideradas responsáveis pelo uso de drogas. Howard Becker criticou esta abordagem psicológica em sua pesquisa com usuários de maconha. Mesmo antes dos anos 1960, sabia-se que para entender como o controle de uma substância colocada no corpo poderia ser desenvolvido, mantido, ou perdido, diferentes padrões de consumo teriam de ser comparados. A esta tarefa dedicou-se Zinberg nos EUA e Inglaterra, no Brasil, os estudos desenvolvidos, entre outros, por 
Edward MacRae e Júlio Simões com usuários de maconha, por Osvaldo Fernandez entre os inaladores de cocaína e por Luana Malheiros entre os usuários de crack, também caminham nesta mesma direção.

Estudos sobre o consumo de maconha, como os levados à frente por Becker e realizados na segunda metade do século $\mathrm{XX}$, nos EUA, provaram que as antigas considerações sobre seus alegados malefícios à saúde eram sem fundamento. A maior parte dos usuários desenvolvia um padrão ocasional e moderado mais que intensivo e crônico. Uma pesquisa sobre os veteranos do Vietnam (ZINBERG, 1984, p. 12) indicou que o consumo de heroína (tida então como a mais perigosa das drogas) nem sempre levava à adicção ou uso disfuncional e, mesmo quando ocorria, a adicção era mais reversivel do que se costumava acreditar. Aparentemente, assim como a crença de que drogas ilícitas eram todas danosas estava perdendo terreno, a crença de que a maioria das substâncias lícitas, como café, açúcar, tabaco e aditivos de alimentos eram todos benignos, também estava. Zinberg sustentou que para entender o que impele alguém a utilizar uma droga ilícita e como esta droga afeta o usuário, três determinantes devem ser considerados de modo interligado: a droga (a ação farmacológica da própria substância), o set (a atitude da pessoa quando do uso, incluindo sua estrutura de personalidade e seu propósito de uso) e setting (a influência do meio, do contexto físico e social em que ocorre o uso). Dos três determinantes, o setting era o que recebia menor atenção, no entanto, tornou-se o foco da sua investigação. Assim, detectou-se que o setting social, através do desenvolvimento de sanções e rituais, possui a capacidade de manter o uso de drogas ilícitas sob controle.

$\mathrm{O}$ uso de qualquer droga envolve valores e regras de conduta (que foram chamados de "sanções sociais") e padrões de comportamento (que foram chamados de "rituais sociais"); estes dois juntos foram designados os "controles sociais infor- 
mais". As sanções sociais definem "se" e "como" uma droga em particular deve ser usada. Elas podem ser informais e compartilhadas por um grupo, como nas máximas associadas ao consumo de álcool: "não misture bebida fermentada com destilada., ou podem ser formais, como nas leis e politicas dedicadas a regular o uso de drogas: "se beber, não dirija". Vemos aqui, portanto, um desdobramento e sofisticação do modelo de Howard Becker analisado por nós anteriormente. Para ele, as sanções sociais ocorrem preferencialmente no âmbito daquilo que ele chama de sociedade abrangente, ou a partir dos não usuários, cabendo aos usuários exercerem alguma sanção no caso da necessidade do neófito passar a dispor de seu próprio suprimento de maconha após seu uso tornar-se um pouco mais constante. Zinberg traz as sanções sociais mais para dentro do grupo de usuários (valores e regras de conduta) e mostra sua importância para a regulação do padrão de uso, assim como leva, ao mesmo tempo, em consideração a importância do ritual (padrões de comportamento).

Corintiano, nosso interlocutor na Cracolândia, entre outros, nos disse a seguinte frase que pode ser entendida como uma máxima entre os usuários por nós contatados: "Você deve saber usar para não ser usado". No caso soteropolitano estudado por Luana Malheiros (2012), a representação do usuário descontrolado cai sobre a figura do "sacizeiro" e isto fica claro no depoimento da usuária Vanessa:

[...] aquele que você reconhece logo; não consegue esconder que fumou crack. Não [es]tá acostumado com a onda e fica no pânico; você reconhece fácil um 'sacizeiro', ele não faz questão de se esconder. Fuma na frente de todo mundo, fica no pânico, não se controla, quer usar toda hora, quando tem a pedra, não quer dividir, é guloso, vive sujo, fedido... Por uma pedra de crack, é capaz de fazer qualquer covardia, não pensa no dia seguinte, só pensa na droga. (MALHEIROS, 2012, p. 85) 
Figura 31 - Sanções sociais

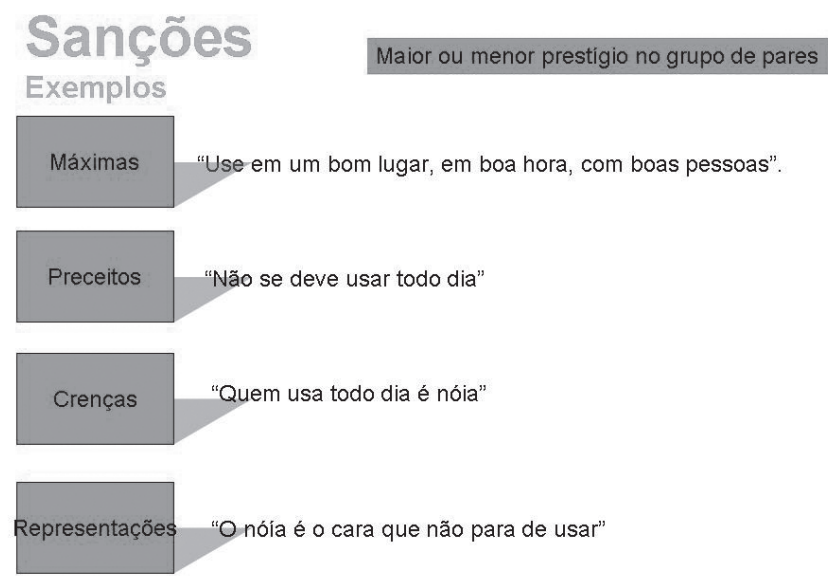

Fonte: Coleção particular do autor.

Os rituais têm relação com os métodos de obter e administrar a droga, a seleção do meio físico e social para uso, as atividades desenvolvidas após a administração da droga e os modos de prevenir os efeitos indesejados. Eles ainda servem para apoiar, reforçar e simbolizar as sanções, colocando-as em relação direta com as pessoas através da prática. Podemos afirmar também, para além de Zinberg, que os rituais fazem mais que relacionar sanções sociais e seus membros. Radcliffe-Brown em seu aclamado livro The Andaman Islanders, de 1922, procurou testar as hipóteses de Durkheim sobre a função dos rituais como a expressão de sentimentos coletivos de uma sociedade; contribuindo para sua coesão e manutenção. Neste sentido, os rituais seriam práticas destinadas a consolidar, ou mesmo sustentar e produzir um sistema de crenças. Porém, em escritos tardios, ele irá defender que os rituais expressam mais que a dependência humana da sociedade; os rituais expressariam, então, a dependência tanto ao contexto físico quanto social. Eles seriam essencialmente expressivos, através de uma maneira de dizer algo além de fazer. A chama- 
da escola de Manchester, da antropologia social inglesa, foi um dos mais importantes frutos desta tradição. Um de seus membros, Victor Turner, dedicou parte de sua obra ao estudo do ritual e nele viu um local de produção de alternativas voltadas, ou não, à manutenção do status quo. Assim, a antiestrutura, estados liminares e potenciais da sociedade, pode ser atualizada e levar à transformação ao expor as alternativas possiveis de destino no drama social. Veremos mais à frente, como a ideia de "communitas" de Victor Turner pode nos auxiliar a compreender a atração exercida pelo contexto social sobre os usuários de crack.

Figura 32 - Rituais, algumas características e interpretações
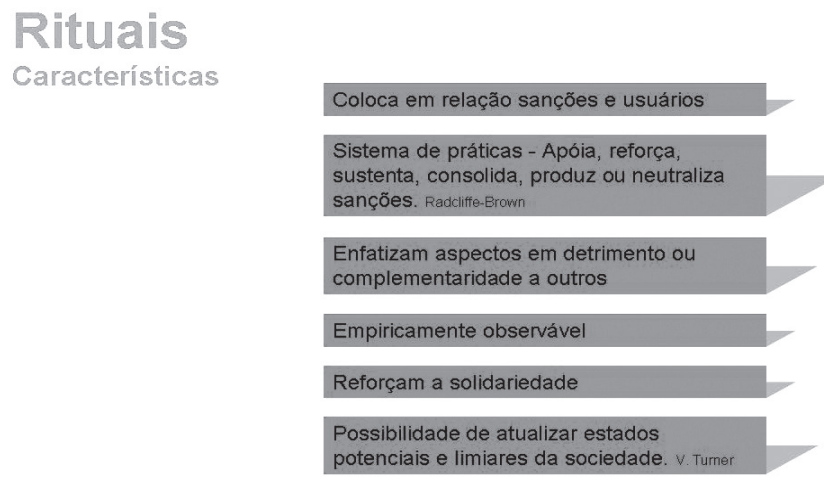

Fonte: Coleção particular do autor.

No caso do álcool, por exemplo, o convite "Vamos tomar uma cerveja" automaticamente coloca algum grau de controle por usar o termo singular "uma cerveja". Por contraste, "Vamos encher a cara" implica que todas as restrições serão abandonadas. Isto exemplifica, uma forma de sanção social por meio de máximas. No segundo caso, mais precisamente, a ausência de sanção ao abuso, ou ainda, uma sanção ao uso moderado da bebida alcoólica. 
Um ambiente propício para pensarmos a relação entre rituais e consumo de álcool são os torneios esportivos universitários, onde se misturam festas, esportes e viagens. As diferentes instituições de ensino rivais possuem suas equipes e respectivas torcidas; faz parte da identidade de certas torcidas ser aquela mais disposta a "aloprar", ou "causar", ou seja, "perder a noção do limite" e "[...] fazer coisas inimagináveis em qualquer momento". (COSTA, 2009, p. 26) Além das festas com quantidades consideráveis de bebida, jogos e brincadeiras são elaborados com a finalidade de se consumir grandes quantidades de álcool, tais como o feitio do "cajuzinho" por um centro acadêmico, a "maratona" da pinga e o campeonato de "bola beque". Uma das variantes do "cajuzinho" foi assim descrita:

[...] a torcida que estava na piscina mobilizou-se para dentro do ginásio transportando os instrumentos da bateria, as bandeiras e um tonel com capacidade para 200 litros, ao qual tinham adaptado uma pequena torneira próxima ao fundo. Quando todos estavam em posição, com o tonel colocado no centro da bateria, começaram a trazer caixas. Havia cerca de cinco ou seis rapazes e cada um transportou pelo menos duas delas, que continham oito garrafas de plástico de $600 \mathrm{ml}$ de pinga cada uma. Conforme eram trazidas, as caixas eram destruídas com certo alvoroço e empolgação e as garrafas distribuídas para a torcida que despejava o conteúdo no tonel. Todos queriam participar conjuntamente do preparo, afinal, o cajuzinho, mais do que uma bebida, é uma forma de estabelecer a união entre os alunos da USP São Carlos. Depois de pronto, bastava colocar a caneca, copo ou garrafa embaixo da torneira e beber o 'suco mágico' do Caaso. ${ }^{90}$ (COSTA, 2009, p. 26, grifo nosso)

A "maratona" corresponde a uma corrida que possui no decorrer do percurso, diversos pontos de parada onde os competidores devem consumir bebida alcoólica, geralmente pinga.

90 Centro Acadêmico Armando Salles de Oliveira. 
Ganha a corrida o competidor mais rápido, mas também o mais resistente à ingestão de bebida em grandes quantidades. No campeonato de "bola beque", ganha o competidor capaz de enrolar e acender um cigarro de maconha no menor tempo. Portanto, consumir bebidas alcoólicas, principalmente a cerveja, faz parte de certo ethos festivo compartilhado pelos estudantes, a partir do qual "se compartilha bebida e são estabelecidas as relações sexuais”. (COSTA, 2009) As competições chegam a reunir 15 mil participantes e o consumo de bebida alcoólica pode chegar a 7 mil caixas de cerveja e 500 de vodca.

Repare que servir os participantes em suas próprias ca-
necas é uma maneira de dividir o que está sendo bebido;
a festa é o momento de partilhar, de trocar e através da
bebida as pessoas estão em relação. A intensidade com
que são consumidas substâncias durante as festas in-
dica essa aproximação; conhecer estudantes de outros
lugares, reencontrar antigos amigos ou mesmo a paquera
é transpassada pelo consumo de bebidas alcoólicas, pois
elas estabelecem uma relação. (COSTA, 2009, p. 37)

Vemos aqui, portanto, como os rituais em torno do consumo de álcool e maconha são importantes na definição dos padrões de consumo destas drogas exibidos por estudantes universitários em seus encontros esportivos. O ritual de beberem juntos, em um clima festivo e competitivo; de compartilharem a mesma bebida feita conjuntamente como o "cajuzinho", completando suas canecas sob a mesma torneira, tudo isto contribui para estabelecer um sentimento de união em torno da bebida compartilhada. Ao mesmo tempo incentiva a beber mais, dado que a bebida os coloca em relação e relacionar-se, sexualmente ou não, com o maior número de pessoas é um dos objetivos destes encontros. A "maratona" é um evento de competição em torno do consumo do álcool, no qual beber grandes quantidades de pinga e resistir fazem o vencedor; ser bem-sucedido neste evento competitivo torna vitorioso não apenas a pessoa, mas o grupo de estudantes 
por ela representado na contenda. Isto posto, vemos como o ritual pode influenciar profundamente o padrão de consumo de álcool nestas ocasiões. Portanto, levar em consideração a ocasião de consumo é de imensa importância e está presente no interior das ideias de Zinberg, correspondendo ao setting de uso. Podemos visualizar esquematicamente como se desenha o setting, segundo Zinberg, da maneira abaixo:

Figura 33 - Contexto físico e social do uso controlado de drogas



Fonte: Coleção particular do autor.

Controles sociais (rituais e sanções) se aplicam ao uso de todas as drogas, não apenas ao álcool e operam em uma gama de settings sociais, variando muito dos grupos sociais abrangentes, representativos de uma cultura como um todo, até um pequeno e discreto grupo. Mas, sanções e rituais tendem a ser mais diversificados quanto mais próximos às circunstâncias. Por exemplo, no uso de drogas injetáveis, não aplicar a droga até que a última pessoa tenha chegado e as portas estejam fechadas. É importante ressaltar que nada garante que as san- 
ções e rituais se desenvolverão como mecanismos de controle de doenças (como o ritual de puxar sangue para dentro da seringa com heroína para em seguida injetá-lo).

Como vimos a partir das ideias de Becker, o grupo de usuários de drogas ilícitas é capaz de fornecer toda uma série de argumentos favoráveis ao seu uso, a despeito da proibição formal. Contudo, os conflitos com a lei, engendrados pela proibição formal, podem causar ansiedade ao usuário e interferir no uso controlado. Pois, na tentativa de lidar com o conflito com a lei, o usuário pode demonstrar mais bravatas, exibicionismo, paranoia, ou sentimentos antissociais do que se estivesse bebendo num bar, ao lado de uma sala de concerto. Este é o tipo de conflito que faz do controle social das drogas ilícitas mais complexo e mais dificil de conseguir que o uso controlado de drogas lícitas.

A paranoia entre usuários de crack é tão marcante quanto a "nóia", e tornou-se sinônimo de craqueiro; comportamentos como olhar insistentemente por um buraco de fechadura, ficar em silêncio procurando escutar algum barulho e andar pelas ruas com ar desconfiado são considerados típicos. Porém, este comportamento não é bem visto pelos demais usuários e no uso coletivo do crack, "os usuários considerados como os mais paranoicos acabam sendo afastados do grupo". (OLIVEIRA, 2007, p. 119)

Vimos neste livro, como existe um ethos subjacente ao uso do crack; nele, a "sintonia" é o sentimento positivo e a radiação, o negativo. A "sintonia" é o sentimento de confiança e empatia entre usuários partilhando a mesma droga, o contexto favorável à "brisa" deleitosa, uma agradável sensação de paz, segurança e comunhão. A "radiação" é seu inverso. Uma "brisa horrenda, medonha" também tem o poder de trazer "radiação", pode "arrastar", ou contaminar todo um grupo e mesmo gerar "aproximação", ou seja, expor aquelas pessoas, chamar 
a atenção sobre elas. Enfim, uma performance desfavorável "Rouba a 'brisa' do outro", como nos declarou o ex-usuário Antônio.

Antônio também nos descreveu um ritual de uso do crack que se dava da seguinte forma. Em um quarto de imóvel abandonado na cidade de Sorocaba/SP, um grupo de aproximadamente seis usuários de crack se juntou para fazer uso coletivo da droga. Todos possuíam uma quantidade razoável de pedras, mas não exatamente a mesma quantidade e um dos participantes não tinha quase nenhum crack. Decidiram fazer o uso em conjunto, portanto, não se preocupando com pequenas frações de pedra que poderiam perder ou ganhar se usassem sozinhos, ou se evitassem usar com este ou aquele participante da roda. Fundamentalmente, o mais importante era permanecerem juntos, usar conjuntamente e em "sintonia". Desfrutar do prazer da companhia reciproca proporcionada pelo consumo de crack, como a bebida para os universitários, no caso dos jogos, o crack coloca pessoas em relação. Como um dos usuários praticamente não possuía pedras para fumar, ele imediatamente assumiu a função de "contenção", ou seja, passou a providenciar água para a roda de fumantes e a servir os "tragos" nos cachimbos. Isto se deu da seguinte forma: seguindo o sentido horário da roda, o "contenção" passa a pedir o cachimbo dos usuários, a começar pelo imediatamente à sua esquerda e, sobre o alumínio perfurado do "boris", prepara um "trago" depositando sobre ele certa quantidade de cinza e depois, uma fração de pedra de crack. O tamanho da fração da pedra depositada no cachimbo dá a dimensão do "trago" a ser sorvido pelo craqueiro. Portanto, é de interesse do craqueiro ter um "trago" condizente com sua vontade de fumar naquele momento, o que não significa necessariamente, o maior pedaço de pedra possivel. 
Figura 34 - Ritual de uso do crack

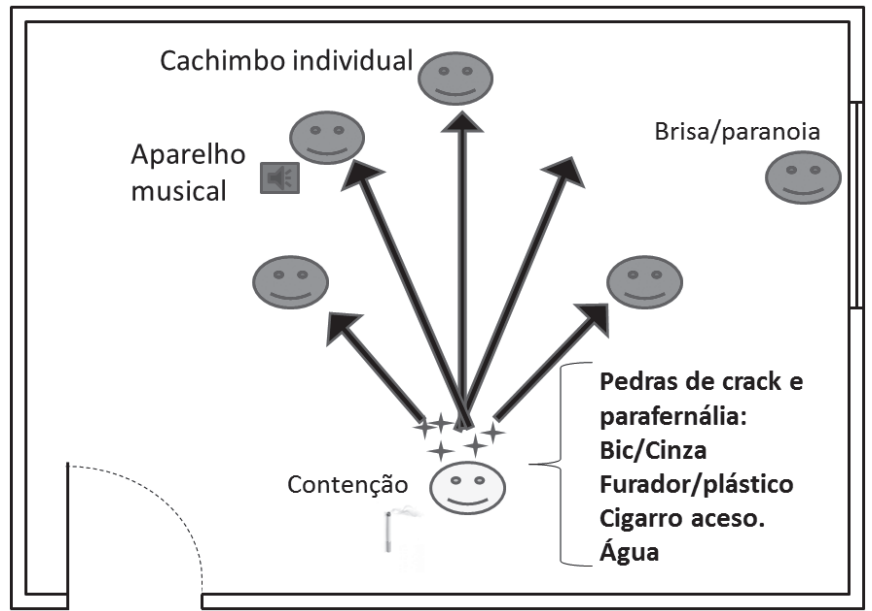

Fonte: Coleção particular do autor.

Vemos, portanto, que o “contenção" desempenha papel importante na roda e é dele também a responsabilidade por servir todos os outros componentes, mesmo estando um deles afastado momentaneamente, por motivo de alguma paranoia qualquer. Antônio nos descreveu certo comportamento de ir até às janelas do imóvel abandonado para respirar um pouco e esperar passar uma "brisa" mais forte, que porventura tenha se abatido sobre algum usuário. Ele poderá estar seguro de que, quando retornar à roda, seu "trago" estará à sua disposição, sem que ninguém venha a "meter o louco", ou seja, tomar vantagem indevida sobre o usuário ausente. $\mathrm{O}$ "contenção" também se responsabiliza por manter sempre um cigarro aceso para proporcionar cinza constante aos cachimbos, assim como pode ajustar o cachimbo de alguém, ou retirar a preciosa "rapa" para novos "tragos".

Há uma série de valores a permear o uso do crack, todos já abordados anteriormente, como: a reciprocidade, o movimento, 
a "sintonia", a honestidade, a confiança e a cordialidade. Quando alguém é "favorecido", ou seja, quando lhe fazem algum favor, ou the fornecem algum bem, como um dos componentes da parafernália, se espera retribuição posterior. A própria "treta" ou troca generalizada de bens e serviços, tem como base a equivalência e o consumo perene da pedra. Assim como as relações necessárias à fruição do crack em um ambiente de uso coletivo dependem de se saber retribuir na justa medida. O "parasita", como visto antes, é a pessoa acusada de imobilismo em um ambiente de uso. Lá, todos devem fazer seu "corre", ou seja, ir atrás dos meios para permanecer no circuito da "treta" e poder usar crack, de preferência em "sintonia" com seus "parças". Portanto, a "sintonia", além de um sentimento de fraternidade entre pares, é também um valor que se contrapõe à "radiação" ou discórdia. Por fim, a cordialidade é o modo preferencial de comportamento entre usuários de crack. O contrário disto seria "meter o loco", ou tratar os demais usuários com desrespeito em um ambiente de iguais e conhecidos muitas vezes de longa data.

O usuário Mariano, de quem tratamos antes, nos contou histórias de frequentadores da Cracolândia que gastaram uma quantidade razoável de dinheiro, um ou dois mil reais, em poucas horas de uso do crack, ficando sem fundos para continuar a "favorecer" seus "parças". Estas histórias exemplares nos mostram a importância de se observar a máxima entre os usuários de crack, de "usar, sem ser usado".

No ritual descrito por Antônio observamos como é importante a "sintonia", a confiança e a honestidade entre usuários em uma roda de crack. Ela também não poderia se manter sem uma grande dose de cordialidade entre seus frequentadores, cordialidade esta que pudemos observar inúmeras vezes, sempre que frequentamos um fumódromo ou a Cracolândia. Para manter a "sintonia", não se pode querer fumar mais que os outros, ou desejar fumar ininterruptamente na roda de crack. 
É fundamental saber aguardar sua vez, esperar, dar-se ao respeito para não ser descortês, nem trazer "radiação" e "roubar a brisa" de alguém.

Podemos, portanto, afirmar que existem valores entre os usuários de crack, nos contextos de uso objeto desta pesquisa, que contribuem para o autocontrole. Um usuário que gaste todo seu dinheiro, ou bens no circuito da "treta" de modo pródigo estará o tempo todo demandando "favorecimentos" por parte dos demais frequentadores do local. Contudo, após, durante e anteriormente ao uso do crack, os usuários estão imersos no circuito da "treta" e para tanto, fazem seus "corres". Tais atividades podem demandar uma maior disponibilidade de pedras, como descrito anteriormente por Zezé. Para seguir em uma "caminhada", em busca de fundos para prosseguir no uso e suprir suas demais necessidades, o usuário se vê na desconfortável situação de ter de fumar para se manter acordado; não para ter "brisa" e tão pouco por prazer. Neste sentido, a situação de rua e o modo como se obtêm fundos joga contra um maior controle no uso do crack. É preciso se manter acordado, em movimento e, ao mesmo tempo, é dificil dormir confortavelmente na rua. Portanto, o usuário de crack, nos ambientes por nós frequentados em nossa pesquisa, tende a desenvolver um padrão de uso por vezes semelhante ao binge, ou seja, um uso até o esgotamento de suas forças. Embora existam pressões, como as exibidas acima, para a moderação, a dinâmica entre estas duas tendências se mostra complexa por relacionar forças distintas em ação constante na "caminhada" de cada usuário.

Mesmo com um padrão de uso muitas vezes semelhante ao binge, devemos considerar que até os mais afetados alcoolistas e adictos, que poderiam ser agrupados no fim do espectro de uso de drogas, exibem algum controle sobre si e sobre seu uso. Eles efetivamente fazem determinadas escolhas sobre se irão usar ou não, em qual momento, com quem e quanto usarão. Observamos isto por diversas vezes no campo com usuários de crack 
que, por exemplo, guardam pedaços de sua pedra para consumir em ocasião mais oportuna. No entanto, Zinberg (1984) nos alertava, há décadas atrás, sobre como permanecia na cultura norte-americana uma profunda aversão em reconhecer o fato de existir uma generalizada preocupação dos usuários, recreativos ou não, das mais diversas drogas, com o controle de seu uso. Como resultado, a cultura norte-americana dos anos 1970 e 1980 do século passado e, porque não, a brasileira do início do século XXI, insistem em diminuir a importância de muitos costumes sociais, sanções e rituais que possibilitam ao usuário de drogas ter certa capacidade de exercer algum controle sobre seu uso. Para ambas as situações, a existência de um módico controle da parte do mais compulsivo usuário e a preocupação geral com o uso de drogas por parte dos usuários mais controlados não podem ser ignoradas. Portanto, o espectro do uso de drogas deve ser ampliado e incorporar o uso ocasional e também o uso controlado, além da experimentação e do abuso de drogas, como na ilustração abaixo:

Figura 35 - O espectro do uso ao abuso de drogas

Experiência - Uso Ocasional - Uso Controlado - Uso Abusivo

Fonte: Coleção particular do autor.

O modo de pensar que ignora o setting social, não é capaz de compreender como o uso de intoxicantes tende a variar a cada fase da vida, status e mesmo localização geográfica. Muitos dos que fizeram uso pesado de intoxicantes quando adolescentes diminuem ao atingirem a maturidade e após mudarem seu setting social (amigos e circunstâncias). Assim como alguns adultos, à medida que se tornam mais bem-sucedidos 
podem aumentar seu uso. Por exemplo, um homem nascido e criado no campo pode mudar seus hábitos significativamente após mudar-se para a cidade grande. Enormes variações de uma época para outra podem também ser encontradas no uso social de intoxicantes, especialmente álcool, em vários países.

\section{Setting. padrão de uso e rituais para Zinberg e o consumo de crack}

Debrucemo-nos um pouco mais sobre a obra de Zinberg porque ela nos permitiu compreender de modo sistemático como o contexto social veio a adquirir imensa relevância teórica para a discussão do uso de substâncias. Nossos dados e conclusões não precisam estar em total consonância com aqueles tão brilhantemente expostos em Drug, Set and Setting. Mas, para os fins deste trabalho, o que nos importa é o modelo para pensar outros contextos. Não pretendemos simplesmente usar um quadro de referências para "outro estado de coisas" (LATOUR, 2012, p. 208), mas nos valer dos conceitos trabalhados por Zinberg para podermos dirigir nosso olhar tanto na pesquisa de campo, quanto na análise de dados. Sem dúvida, existem diferenças entre o uso de psicoativos nos EUA e na região central da cidade de São Paulo; também entre este uso nos anos 1960 e 1970 e o realizado atualmente. Porém, mais que uma moldura a conter nosso pensamento, o modelo pode servir para nos propor caminhos, direções e enfim, nos inspirar. ${ }^{91}$

No Vietnam, as evidências descritas acima, mostram que a droga era utilizada pesadamente para obscurecer os acontecimentos da guerra, com pouca atenção ao controle. Porém, muitos veteranos usaram heroína no Vietnam, sem tornarem-se adictos. Cerca de metade dos homens que usaram heroína no Vietnam e que eram adictos, usaram heroína após a volta aos EUA e

91 Ademais as razões expostas, não existem até então, em língua portuguesa, uma descrição mais aprofundada do modelo zinberguiano. 
apenas $12 \%$ tornaram-se readictos a ela. O setting terrivel da guerra, embora pudesse ser compensado pelo companheirismo entre militares, foi responsável por certo padrão destrutivo de uso. O setting das ruas do centro de São Paulo, por nós encontrado em nossa etnografia, possui seu aspecto de "communitas". Mas, certamente, a rua como a guerra, impõe condições dramáticas para a sobrevivência e não poderia ser diferente para os usuários do crack. Para Zinberg é necessário compreender em cada caso como as características específicas da droga e da personalidade do usuário interagem e são modificadas pelo setting social e seus controles. Vejamos o quadro abaixo:

Figura 36 - Setting e padrões de uso de drogas

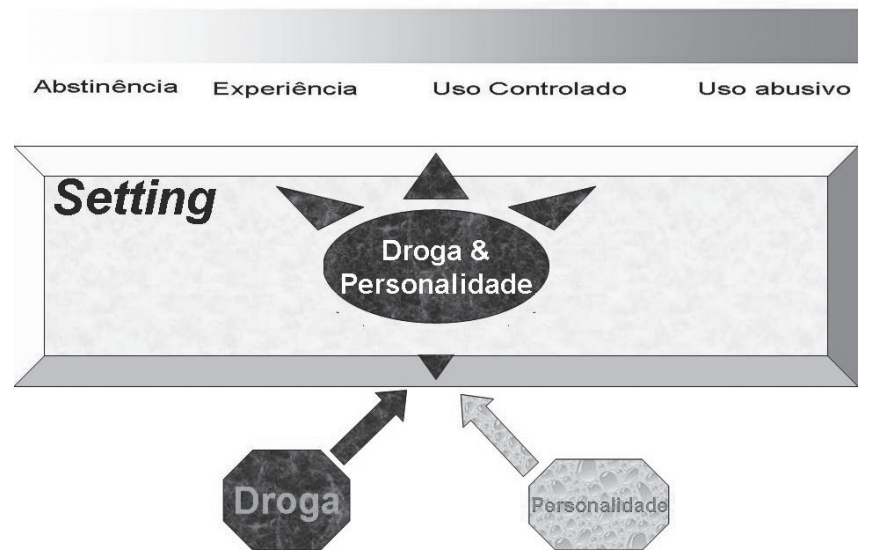

Fonte: Coleção particular do autor.

A cultura americana, como vimos acima, não reconhece plenamente, muito menos apoia o uso controlado das drogas ilícitas. Os usuários são declarados "desviantes", como uma ameaça à sociedade, ou como "doentes" e necessitados de ajuda, ou ainda "criminosos" e merecedores de punição. Este quadro não se diferencia substancialmente no cenário brasileiro. Socializa- 
ção centrada na família para o uso não está disponivel, portanto, os pais dizem aos filhos para não usarem drogas porque são prejudiciais e os jovens desconsideram este aviso porque sua própria experiência lhes diz o inverso. Seu grupo de usuários e a cultura da droga reforçam sua própria descoberta de que o uso de drogas em si e por si não é ruim ou mal e que os avisos vindos do mundo adulto são irreais. Os jovens poderiam simplesmente pensar: "Eles estão errados sobre maconha; porque eu deveria acreditar no que eles dizem sobre cocaína?". Se os pais tentam uma abordagem diferente e dizem aos jovens que algumas drogas são tranquilas, mas outras têm um componente de alto risco e deveriam ser evitadas, sua posição novamente é vulnerável. Além do mais, por aconselhar suas crianças que algumas drogas ilícitas são menos danosas que outras, os pais são colocados em uma posição dificil em ter de aprovar uma atividade ilegal e seu papel como transmissores da moralidade pública fica evidentemente inconsistente. Caso os pais queiram obter conhecimento de primeira mão experimentando drogas, terão de lidar com a inversão do papel tradicional entre instrutor e pupilo. Esta situação cria enorme ansiedade nos pais e dificilmente eles conseguem sentir os efeitos. Resumindo, para Zinberg (1984) o uso de drogas ilícitas é uma situação sem vencedores para todos, mesmo para aqueles que tentam planejar e ensinar cursos úteis de educação sobre drogas.

No caso da mídia de massa, muito da informação provida é dramaticamente oposta ao uso de drogas e à possibilidade de uso controlado. Sem a família, a escola e a mídia, a tarefa cai diretamente sobre o novo grupo de pares $^{92}$ - um substituto inadequado da geração cruzada, da socialização de longo termo. Associar-se com usuários controlados é uma questão de sorte. No início de suas carreiras como usuários, os indivíduos

92 São os agentes presentes no contexto de quem inicia o uso de alguma droga. No caso do uso controlado, os agentes presentes nos rituais de uso são geralmente, outros usuários controlados. 
podem se envolver com outros tipos de grupo, cujos membros não estejam escolados no uso controlado, ou em um grupo em que o uso compulsivo e comportamento de risco sejam as regras. Eventualmente, estes sujeitos podem se tornar usuários controlados, mas somente após eles terem se realinhado com novos companheiros - uma dificuldade e um processo incerto. Infelizmente, muitos usuários adolescentes nunca fazem esta transição. Vimos anteriormente, como Antônio iniciou seu uso de crack em um grupo majoritariamente constituído por pares inexperientes e com apenas um único usuário mais antigo, porém, apegado a um padrão possivelmente abusivo, isto certamente não contribuiu para uma socialização no uso do crack voltada ao uso mais controlado. O caso de Esmeralda é ainda mais dramático. Ela encarava na rua, toda uma população usuária abusiva, além de um ambiente físico que dificultava a rotina de sono diário.

Figura 37 - Grupo de pares e padrão de uso

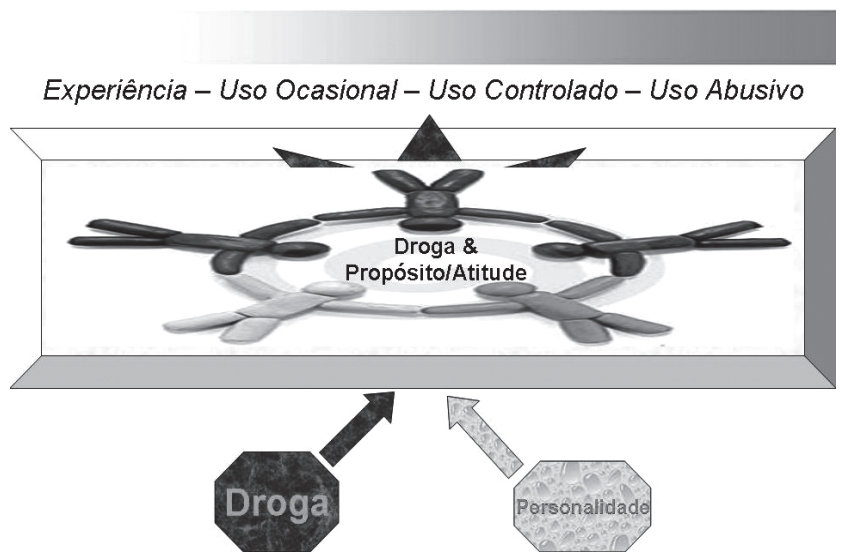

Fonte: Coleção particular do autor.

No caso dos usuários de heroína, as variações de força e pureza fazem da tarefa de controlar dose e o efeito fica mais dificil. 
Além disto, a política proibicionista contribui ativamente para a prevalente dicotomia entre abstinência e uso compulsivo. Isto se torna extremamente complexo para alguém que queira usar drogas e escolher um padrão de uso moderado. Mesmo assim, os rituais de controle e sanções funcionam para Zinberg (1984) em quatro modos básicos e sobrepostos, ${ }^{93}$ a saber:

- As sanções definem uso moderado e condenam uso compulsivo, no caso dos usuários de crack, ouvimos do nosso interlocutor por diversas vezes a seguinte máxima: "Você deve saber usar para não ser usado". Já os usuários controlados de opiáceos pesquisados por Zinberg têm sanções limitando frequência de uso a níveis abaixo que os requeridos para adicção e muitos têm sanções especiais como "não use todo dia”. Um ritual completando esta sanção restringe o uso aos finais de semana. Veremos mais à frente, como o Programa DBA possibilitou aos usuários de crack rapidamente desenvolver rituais relativos a trabalho, estudo, alimentação e sono capazes de servir como sanções ao uso imoderado de crack;

- As sanções limitam o uso a cenários, ambientes, contextos físicos e sociais, como por exemplo, a máxima para psicodélicos: "Use em um bom lugar, em boa hora, com boas pessoas". Dois rituais consonantes com esta sanção são selecionar um cenário rural aprazivel para o uso do psicodélico e a hora do uso para evitar dirigir "viajando". Entre nossos

93 Zinberg trabalha as sanções sociais aparentemente sob influência de Durkheim, para ele, os fatos sociais consistem em "maneiras de fazer ou de pensar, reconheciveis pela particularidade de serem suscetiveis de exercer influência coercitiva sobre as consciências particulares". (DURKHEIM, 1995 , p. 28) Esta coerção social é devida "ao prestígio de que estão investidas certas representações [...] os hábitos individuais ou hereditários apresentam esta mesma propriedade: dominam-nos, impõem-nos crenças ou práticas. Todavia a dominação é interior; pois os hábitos existem por inteiro em cada um de nós. Ao contrário, as crenças e práticas sociais agem sobre nós a partir do exterior: assim a ascendência exercida por um e outro é muito diferente". (DURKHEIM, 1995, p. 29) 
interlocutores usuários de crack, antes do Programa DBA, os rituais de uso se prendiam a seleção do barraco como ambiente propício e a se evitar fumar na presença de crianças e do "Zé Povinho";

- As sanções identificam efeitos potencialmente indesejados e os rituais incorporam as precauções a serem tomadas antes e durante o uso. Usuários de opiáceos podem minimizar o risco de overdose usando somente uma parte da droga e esperando para calibrar seus efeitos antes de usar mais. Usuários de crack de certa forma dosam quantidades de Corote, ou pinga com o crack, dependendo de seu objetivo no momento. Muitas vezes a cachaça pode ser utilizada para proporcionar coragem em um "corre" mais arriscado. O uso do álcool também está ligado a precaução contra os efeitos indesejados do uso do crack, como a paranoia. Além disto, eles procuram alimentar-se e levam água à "biqueira";

- As sanções e rituais operam para compartimentalizar o uso de drogas e apoiar as obrigações não relacionadas ao uso por parte do usuário e seus relacionamentos. Usuários podem orçar a quantia em dinheiro que gastam em drogas, como fazem para entretenimento, ou podem usar apenas à noite ou finais de semana para evitar interferir no desempenho no trabalho. Isto foi testemunhado por nós a partir da implantação do Programa DBA e veremos mais à frente. O quadro abaixo mostra a relação entre rituais e sanções relacionadas ao uso de drogas.

O processo pelo o qual rituais de controle e sanções são adquiridos varia de sujeito para sujeito e sem dúvida, para Zinberg (1984), o mais importante recurso de preceitos e práticas para controle é o grupo de pares. Apesar da imagem popular da pressão dos pares como uma força corruptora empurrando indivíduos frágeis para o abuso de drogas, suas entrevistas 
mostraram que muitos segmentos da cultura da droga haviam tomado uma firme posição contrária ao abuso de drogas.

Figura 38 - A relação entre rituais de uso e sanções

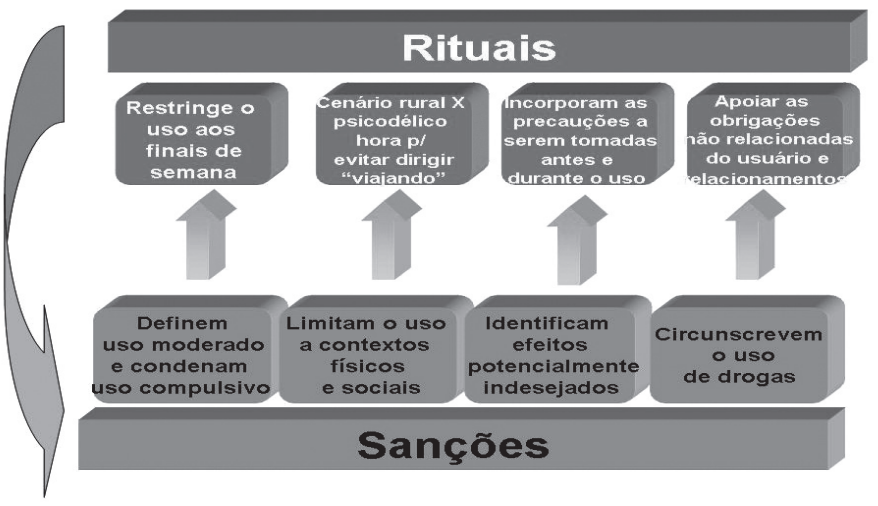

Fonte: Coleção particular do autor.

Ao deixar de tratar do uso controlado para iniciar suas considerações sobre o abuso, Zinberg irá fazer uma revisão histórica para determinar a genealogia do termo "abuso de drogas". Corroborando outros autores como Hart (2014) e Escohotado (1989), Zinberg observa que o uso desse termo aparentemente tivesse sido aplicado primeiramente ao uso de cocaina por negros do sul dos EUA. Originalmente, refletia preconceitos de raça e classe contra usuários negros, destacando a respeito dos efeitos perigosos da cocaína. Esse estigma foi estendido ao uso de ópio pelos chineses expressando o medo de uma minoria desprezada. O Harrison Narcotic Act, de 1914, colocou sob o termo "abuso de drogas", o uso de morfina e heroína. Uma serie de regulamentações posteriores da Suprema Corte transformou o uso não subscrito de opiáceos de um mau hábito em atividade criminal. Mesmo médicos perderam seu direito a prescrever opiáceos. Adictos do meio rural, incapazes de 
abandonar a droga, moveram-se às cidades costeiras onde os mercados ilegais cresceram e a animosidade pública em volta da adicção se desenvolveu.

O termo "adicção" mudou de significado no início do século $\mathrm{XX}$, de mau hábito da guerra civil, doença do soldado, o uso não prescrito de morfina se espalhou e passou a ser evidência de fraqueza de caráter ou mesmo de degenerescência. Até então, opiáceos eram "medicamentos próprios de deus" e apesar de desaprovada, a adicção era tolerada. Era específico de mulheres brancas rurais vistas com pena. Entre os anos 1910 e 1920, a palavra "adicção" começa a ser aplicada ao uso culturalmente desaprovado de certas drogas, tanto quanto o termo "abuso de drogas" é usado hoje. Em 1912, Charles B. Towns descreveu o que chamou de "tríade adictiva": fissura crescente, aumento da tolerância e sindrome de retirada. Hoje, segundo Zinberg (1984), adicção é genericamente aceita como um termo científico que descreve a dependência fisiológica inevitável que acompanha o continuo e pesado uso de substâncias (como opiáceos, barbitúricos, ou álcool) que possuam certas características farmacológicas.

Numa postura crítica a esta visão, primeiramente, é impossivel, para Zinberg, definir "crescimento da fissura" precisamente, ou limitar esta noção ao abuso de drogas. O viés por trás da definição é que fissura conota fraqueza e senso de desespero que pode levar ao comportamento antissocial e até mesmo ao criminal. Por outro lado, a tolerância crescente a certa droga foi aceita como progressão aritmética: após alguém usar uma substância certo número de vezes irá precisar de um aumento correspondente na quantidade para obter o mesmo efeito. Esta ideia ignoraria as importantes diferenças entre os indivíduos sobre como conseguem lidar com quantidades diferentes de drogas.

Para o médico e professor de Harvard, uma razão para a prevalência de definições de abuso de drogas que não são nem 
lógicas ou científicas é a força do moralismo puritano na cultura americana, que desaprova o prazer e a recreação proveniente de intoxicantes. A ideia de que o prazer, ou melhor, o tipo de prazer que leva ao escapismo e euforia, é potencialmente perigoso e precisa ser racionado estaria impresso na consciência americana. Porém, tal como observou Becker (2008), muitos usuários de maconha e psicodélicos consideram que seu uso de drogas é aceitável e prazeroso e desafiam a sua definição social como desviantes. Por outro lado, a pesquisa de Zinberg revelou como mesmo usuários moderados também refletiam atitudes e valores puritanos ao se culparem pelo seu uso. Então, usam por propósitos "sérios" como na intenção de obter inspiração (insight) pessoal ou religiosa - e expressam desdém e até rotulam como abusadores aqueles que procuram prazer. Os acusam de desejarem apenas ficar altos e aproveitar sua experiência psicodélica de um modo sensual. Lembremos que para Timothy Leary e seus seguidores nos anos 1960 do século passado, o LSD era chamado de sacramento.

A imposição da moralidade puritana sobre assuntos científicos para definir abuso de drogas é também aparente no desacordo encontrado na literatura científica sobre a natureza da adicção - especialmente da heroína. Zinberg observa como alguns estudiosos comparam o efeito da heroína ao orgasmo sexual e vimos a mesma comparação entre uso de crack e orgasmo no Brasil.

Fumar uma pedra de crack é comparado a uma quantidade de neurotransmissores iguais à de um orgasmo. Com a diferença de que se pode ter um orgasmo a cada cinco minutos. Nenhum ser humano, com uma vida normal, pode isso! Essa é a grande questão: os fatores associados à rapidez com que o usuário se torna dependente químico. (VIDAL, 2013, p. 1)

Diferentemente do propalado orgasmo, depois de prolongado uso de heroína, os sujeitos investigados por Zinberg experi- 
mentaram, segundo ele, uma desejável mudança de consciência caracterizada por aumento da distância emocional muito aquém da euforia, ou seja, o efeito procurado no uso da heroína era algo muito distante do orgasmo. Fato semelhante, não no efeito propriamente dito, mas em seu distanciamento do orgasmo pudemos verificar entre nossos interlocutores usuários de crack. A "brisa", procurada na forma de "sintonia", se mantém muito distante do apelo sexual, embora tenhamos percebido ser o "Morrinho", ao lado da "biqueira" a céu aberto, um local para encontros amorosos entre usuários de crack e também tenhamos presenciado seu uso entre casais nos barracos.

Portanto, para Zinberg, o abuso de drogas não pode ser definido em abstrato, precisa ser determinado em uma base de caso a caso. Ele terá dois padrões de mensuração: quantidade de uso e qualidade de uso. Quantidade de uso se refere ao tamanho e frequência da dosagem. Qualidade concerne a como a droga é usada ou as condições de uso que inclui o modelo de uso e o contexto social (quando, onde e com quem a droga é usada), ou seja, o conjunto de condições de uso da droga quanto ao local na qual é usada, o grupo de usuários com quem se compartilha o uso e o encadeamento das diferentes ocasiões de uso.

Em Zinberg (1984), apenas nos casos de doses em níveis extraordinários seria pertinente se considerar a quantidade de uso como evidência padrão para diferenciar uso de abuso. Segundo ele, fora destes níveis, medir quantidade pode não ser um modo prático de medir abuso e mais, o modelo da quantidade não é igualmente aplicável a todas as drogas. No caso da maconha é difícil estabelecer uma dose abusiva. Vimos acima, como para Becker (2008) sequer esta possibilidade á cogitada, dado partir este autor da premissa de ausência de uso problemático da substância. Porém, para Zinberg, os usuários pesados de maconha se assemelhariam àquelas pessoas habituadas a tomar um comprimido para dormir, mesmo após este não 
ser mais necessário em termos da falta de sono. Ele considera, portanto, quantidade (incluindo frequência) uma variável de difícil comparação e quando ele tenta diferenciar a quantidade mínima de um experimentador para um usuário ocasional, chega ao acordo na frequência de mais de uma vez por mês para uso ocasional. Porém, encontra ainda mais dificuldade em decidir por um critério para o uso máximo e, acaba por fazer da qualidade do uso seu maior critério. Assim, podemos concluir com Zinberg a respeito da qualidade do uso de drogas e das dificuldades em bem utilizar este conceito:

Julgamentos sobre qualidade do uso devem levar em conta uma complexa gama de fatores. Aqui o elemento social é geralmente mais importante que o farmacológico. Ter a prática regular de começar um longo dia de bebedeira cedo de manhã é bem diferente de ocasionalmente ingerir uma dose de LSD a mesma hora do dia. O uso do álcool - um depressivo significativo do sistema nervoso - como um 'abridor de olho' matutino é um claro indicador de problema. O que também será verdadeiro sobre o LSD se seu uso for da mesma natureza compulsiva; mas se a dose matinal de ácido tiver sido cuidadosamente planejada e for acompanhada por atividades específicas, usualmente levadas em um cenário social, a qualidade do uso será radicalmente diferente. (ZINBERG, 1984, p. 44, tradução nossa)

Durante a década de 1970, nos EUA, ocorreram mudanças drásticas na qualidade do uso que tornaram a experiência com LSD menos cataclísmica. Esta diferença se dará, na opinião de Zinberg, devido a mudanças principalmente no propósito de uso. No início dos anos 1970, a admissão de usuários de psicodélicos para tratamento em serviços de saúde mental por episódios psicóticos agudos e mesmo de longo termo, passiveis de ocorrer frequentemente no final dos anos 1960, desapareceu por completo. Ele observou um importante dado da National Commission on marihuana and Drug Abuse a respeito da quantidade de psicodélico usada; ela não declinara até 1974. Ainda mais, desde que os recursos psiquiátricos estabelecidos não fo- 
ram capazes de lidar com as más experiências com drogas com sucesso, a contracultura havia começado a invocar seu próprio "pessoal" experimentado para lidar com as más viagens. Muitos usuários, ademais, estavam dispostos simplesmente a ter uma má viagem, sabendo ser o problema um efeito transitório da droga e não um indicativo de insanidade. Mesmo aqueles entre os sujeitos investigados na pesquisa de Zinberg com histórico de uso pesado de psicodélicos, não costumavam mostrar interesse no pensamento religioso do oriente ou em um estado de consciência mais elevado, fato comum alguns anos antes. $\mathrm{O}$ novo contexto social, um elemento qualitativo, parece ter sido o fator predominante nesta mudança, esse ambiente era marcado por um uso mais hedonista e menos afeito às buscas espirituais. Porém, Zinberg não nega o fato de viagens frequentes de ácido em curto período de tempo poderem resultar em uma mudança de perspectiva e modificações intrínsecas de personalidade. Estas mudanças poderiam ser interpretadas pelos usuários como, por exemplo, um crescente interesse em abstração e espiritualidade. No entanto, o mais importante fator de proteção seria a diminuição da vulnerabilidade de usuários inexperientes, posterior ao desenvolvimento da sanção: "use a primeira vez sempre com uma pessoa experiente".

Para resumir, abuso de drogas em Zinberg (1984) pode unicamente ser determinado em bases individuais, pela observação de efeitos adversos do uso, por exemplo. Abandonar o termo "abuso de drogas", segundo este autor é um pré-requisito necessário para entender porque e quando pessoas usam drogas, como elas as usam, e, acima de tudo, se elas podem usá-las com sucesso - quer dizer, de modo controlado. Libertar-se da ambiguidade de uma das palavras código enunciadoras de um pensamento errôneo da sociedade sobre o uso de drogas dará aos investigadores a chance de encontrar e empregar termos claros, precisos e realísticos, além de tornar possivel enfrentar o desafio de desenvolver e estender um controle sobre o comportamento de tomar drogas. 
A adoção do termo "uso controlado" ao invés de "uso ocasional" na pesquisa de Zinberg reflete o interesse em entender quão controlado - ou seja, quão consistente e bem sucedido - tal uso ocasional poderia ser. Interessa-o ainda pensar como o dano potencial do uso de drogas poderia ser minimizado e encontrar sujeitos que fossem moderados e cuidadosos a respeito de seu uso de drogas. O mais óbvio requisito é que os candidatos não fossem usuários tão frequentes que seu uso pudesse interferir com sua vida familiar, amigos, trabalho ou escola e saúde. Múltiplos usos diários de maconha, heroína, ou LSD, assim como seu uso diário, foram eliminados imediatamente. Assim sendo, se recrutaram sujeitos que haviam usado uma vez por semana ou menos por todo último ano, ao menos até a entrevista inicial. Assim, ter sucesso no uso seria conseguir desfrutar os efeitos recreativos desejados e evitar as consequências negativas como overdoses, badtrips e sindromes de abstinências.

Se for para levarmos a sério a ideia de contexto social trazida por Zinberg e a partir daí buscarmos uma melhor compreensão do uso de crack nas ruas do centro de São Paulo, devemos nos perguntar qual o significado de uso controlado de crack para pessoas em situação de rua, particularmente para aquelas que vivem em "biqueiras", ou na Cracolândia. Não podemos, é claro, assumir os critérios de Zinberg, com relação à frequência semanal de uso, mas podemos ter como parâmetro a qualidade das relações com o entorno, o setting do usuário. Um critério possivel para diferenciar o "nóia" do "usuário" é capacidade de não ser um "parasita", de conseguir "fazer seu corre" e ser respeitado na "biqueira”. Seja como usuário, "vapor", "contenção", "sintonia", ${ }^{94}$ disciplina, ou qualquer outro papel que se atribua a quem usa crack e vive no entorno de um espaço psicotrópico. No caso baiano, vimos no trabalho de Malheiros (2012), como o perfil do "sacizeiro" se diferencia do usuário; em nossa

94 "Sintonia" é um papel atribuído pelo PCC aos seus prepostos nos locais de comércio e uso de crack. 
pesquisa participante pudemos perceber claramente o repúdio ao "parasita" e a importância de se observar a máxima: "usar sem ser usado". Como nos declarou certa vez Dobem: "existem aqueles que se entregam", ou seja, para além de "ser do crack", certos usuários seriam usados pela droga ao invés de usá-la. Assim, vemos a importância de considerar o padrão de uso de nossos interlocutores no interior das expectativas relativas a seu grupo de pares, ou seja, seus amigos ou "parças".

Padrões de amizade e atividades do grupo de pares jogam o papel mais importante na influência dos estilos de uso controlado e compulsivo. A mais importante diferença, na pesquisa realizada por Zinberg (1984), foi que usuários controlados tendem a possuir mais amigos e associados. Nenhum sujeito controlado era um "solitário", comparados aos 11\% dos compulsivos e mais, 68\% dos sujeitos controlados, comparados a 37\% dos compulsivos, tinham "vários grupos de amigos". Compulsivos não apenas sofriam uma redução drástica nos amigos, mas os que eram solitários afirmaram serem assim porque os amigos os haviam abandonado. ${ }^{95}$

O modo como um indivíduo usa drogas é influenciado pelo modo como seus associados as usam, ou seja, sujeitos controlados tendem a conhecer mais usuários controlados que compulsivos. Evidentemente, sujeitos controlados mantém uma rede mais ampla de conexões sociais - um grupo de pares mais

95 Existe um impressionante padrão de diferenças entre os dois grupos, não controlado e controlado, pesquisados por Zinberg quanto à motivação para o uso, assim, mais compulsivos que usuários controlados declararam os primeiros quatro motivos para usar: "viajar", "sair da realidade", "correr perigo" e "aliviar a depressão". Ao segundo grupo de motivações "gostar da onda", "uso social", "recreação" e "relaxar" - que podem ser conceitualizados como uso social ou celebratório. Em todos os casos mais usuários controlados que compulsivos tiveram estes motivos "saudáveis". Estes dados aparecem para emprestar apoio à visão que o uso compulsivo representa um tipo de automedicação, uma tentativa de acalmar um estado de dor interna. Há uma boa razão para supor, entretanto, que no caso de nossos usuários compulsivos de crack, isto foi afinal muito mais consequência do contexto - o isolamento e o stress ambiental resultante da situação de rua. 
largo - que os proveem com retornos valorizados e reforço para o uso moderado, enquanto sujeitos compulsivos, que tendem a conhecer mais usuários compulsivos e menos usuários controlados e que também tendem a ser solitários, parecem ficar fora do campo de influência dos usuários mais moderados.

A situação de rua revelou-se em nossa pesquisa como o ambiente privilegiado para alguém relacionar-se com outras pessoas que fazem uso cotidiano de crack e Corote, ${ }^{96}$ especialmente. Para poder estar no "corre", principalmente o de tipo mais arriscado e no intuito de sobreviver às noites perigosas da região central, muitas vezes sem dispor de um barraco e mesmo dispondo, sujeito a interrupções constantes, como é o caso de uma "biqueira" a céu aberto. Vimos como, no sentido de "manter-se alerta" para suportar sua "caminhada", a companhia de outros "parças" na mesma situação, dispostos a manter seu uso, sem cair no papel de "parasita" é fundamental. Portanto, a companhia de "parças" e "usuários fortes" de crack é uma maneira de sobreviver na rua e este fato corrobora a ideia central a Zinberg relativa à importância do grupo de pares e seu padrão de uso. O padrão binge prevalece na rua, muito pela influência do entorno. Se usa droga até o total esgotamento porque o ambiente não permite o descanso reparador; pela necessidade de se estar na segurança da companhia de conhecidos que, por sua vez, também são usuários pesados.

A proximidade desenvolvida ao se compartilhar uma experiência ilícita e prazerosa dá ao usuário um senso de pertencimento a algo especial e impróprio que não á conhecido pelo "mundo careta". Maconha certamente provê um tópico especial de conversação. Isto faz o usuário se sentir como um membro de um clube. Com relação aos não usuários, muitos dos sujeitos pesquisados por Zinberg reportaram estranhamento frente a velhos amigos que não usam, por temer críticas e desaprovação. Sobre os efeitos do LSD, a pesquisa de Zinberg detectou

96 Popular marca de aguardente. 
certa influência nos relacionamentos, um tipo de ligação poderosa entre as pessoas que "viajavam" juntas. Um sentimento de proximidade pessoal. A experiência compartilhada parece estabelecer um sentimento de afinidade.

As características empatogênicas das drogas são aquelas relacionadas à sua associação com a produção de sentimentos de empatia, amor e proximidade emocional entre seus usuários. Estas características foram estudadas pela primeira vez de um modo específico pelo psicólogo alemão, radicado nos EUA, Ralph Metzner, companheiro de Timothy Leary em seus estudos com LSD em Harvard, no início dos anos 1960. Um dos entrevistados por Zinberg descreve assim os efeitos empatogênicos do LSD:

Eu nunca havia falado tão abertamente sobre mim antes na minha vida. E foi fácil. Eu não me senti, você sabe, como escondendo nada sobre mim, ou que o que eu era tão terrivel. Então, ele me contou sobre ele e eu pude entendê-lo e me sentir próximo e pensar que tudo que me disse sobre ele era ok, assim como era comigo. (ZINBERG, 1984, p. 103)

Ainda mais destacado que o LSD neste sentido, a metilenodioximetanfetamina (MDMA), ou Ecstasy é reconhecidamente como uma droga empatógena. Examinemos como a empatogenia vem a ser um dos efeitos procurados no uso do crack e ainda, como a "sintonia", termo êmico para designar a empatogenia do crack pode ocorrer sob determinadas condições. Em nossa pesquisa de campo tivemos a oportunidade de presenciar, como já descrevemos anteriormente, o uso de crack em condições caracterizadas pelos usuários como profundamente empáticas, ou com "sintonia" entre eles. Ao mesmo tempo, tivemos relatos de convivência dificil com familiares e uma progressiva aproximação dos outros usuários de crack. Foi o caso de Mariano, um morador da Cracolândia, que teve desavenças com sua avó devido à intolerância desta em relação ao seu hábito. 
Não observamos, entre nossos interlocutores, descrição de situações prazeirosas de contato com não usuários de crack quando sob efeito da droga, ou de desejo em participar de ocasiões sociais desvinculadas do uso, como as descritas por Zinberg entre os usuários de LSD, chegando estes a irem à igreja para conversar durante os efeitos do alucinógeno. Pelo contrário, possivelmente por tratar-se de usuários em situação de rua, as descrições foram de um forte sentimento de inadequação quando em situações não relacionadas ao uso de crack, ou à vida na rua. Abaixo, um trecho de uma conversa com um interlocutor, em seu barraco sobre as dificuldades em relacionar-se fora da "biqueira":

Zezé - Fome. A fome de usuário acumula porque a gente queima gordura, mas tem uma hora que a necessidade de comida é tão grande que um arroz azedo é banquete. Quando você vê usuário mexendo no lixo. Ele perde totalmente a vergonha, o pudor, o preconceito, ele se desveste de qualquer formação psicológica e social quando tem fome.

Ygor - Se você andar na rua agora, você acha que as pessoas te vêm como usuário, ou não?

Zezé - Sim, porque as pessoas percebem o mau tratamento com o corpo. Hoje você está me vendo limpo, porque tomei um banho. Mesmo tendo tomado banho você vê mais uma pessoa que se preocupa em ter o crack fumado do que cuida da sua aparência e higiene, cabelo, barba.

A ida à rua aparece como um clamor do corpo por alimento e ao mesmo tempo, este corpo carrega os estigmas desqualificantes capazes de inabilitar o indivíduo "para a aceitação social plena". (GOFFMAN, 1975, p. 7) A fome leva do barraco à rua e esta empreitada no universo das interações sociais com não usuários conduz à possibilidade de exposição aos olhares e julgamentos do "Zé Povinho". Esta exibição involuntária abre a possibilidade de os sinais corporais mencionados por Zezé, como o cabelo descuidado, a barba mal feita, a sujeira, enfim, o 
maltrato com a aparência e higiene revelarem seu status moral. Este faria do usuário de crack, possivelmente, "um escravo, um criminoso ou traidor". (GOFFMAN, 1975, p. 11) Teríamos assim, configurados os escravos da droga passiveis de cometer qualquer crime sob abstinência e ainda representados, contra sua vontade, como traidores da ética do trabalho, tal qual os usuários de drogas norte-americanos pesquisados por Zinberg. Porém, em nosso caso, o contexto é ainda particularmente marcado pela ideologia da "São Paulo que não pode parar".

A sujeira, o descuido com o corpo e a perda da "vergonha" e do "pudor" por parte do usuário de crack disposto a remexer o lixo, como nos assinalou Zezé, acabam por formar uma gama de atributos capazes de colocar certos indivíduos em uma determinada categoria, ainda mais ao encontrarem-se no ambiente da rua. A categorização cria uma série de expectativas não apenas quanto ao comportamento do outro, mas também expectativas quanto à identidade social de alguém. Assim, é possível ao não usuário apropriar-se de certa maneira estereotipada de relacionar-se com estas pessoas, uma "rotina de relação social" (GOFFMAN, 1975, p. 12) para interagir com o "zumbi usuário". Ser "nóia”, craqueiro ou zumbi é carregar uma série de atributos depreciativos capazes de estigmatizar alguém, assim como de confirmar a normalidade de outro.

O usuário de crack se considera, portanto, um desacreditado com características distintivas desqualificantes imediatamente evidentes ao olhar do outro. Assim, outros atributos que estes indivíduos possam por ventura carregar consigo ficam impossibilitados de se mostrar a atenção daqueles com quem venham interagir. Tal a força do estigma em provocar no "Zé Povinho" a tendência a inferir "uma série de imperfeições a partir da imperfeição original”. (GOFFMAN, 1975, p. 15) O usuário de crack possui consciência disto, tanto que despreza o "Zé Povinho", mas também se envergonha na interação com ele. O termo "Zé Povinho" resume o ponto de vista do usuário de 
crack sobre os ocupados transeuntes da capital paulistana, ao movimentarem-se pela cidade, envoltos em seus afazeres. Em meio a vida agitada da metrópole, os paulistanos são capazes de encontrar tempo disponível para apontar em direção a eles, criticar, falar mal, enfim, demonstrar seu julgamento desqualificante através de um comportamento hostil com relação aos corpos dispostos nas calçadas, sob os barracos. Comportamento dedicado àqueles que portam seu cachimbo e possuem sinais físicos próprios do uso do crack na rua, como magreza, olhos embotados, andar trôpego, mãos enegrecidas e má vestimenta.

Procuramos demonstrar aqui como as atividades necessárias para a obtenção da substância são vividas de forma por muitas vezes prazerosa. É como se o uso da substância proporcionasse um tempo vivido no qual, atividades sociais, ocupacionais ou recreativas são trocadas por outras atividades mais interessantes como o "corre" e a "treta". Pessoas fumando, bebendo e se alimentando em roda são uma das atividades mais tipicamente sociais conhecidas. A análise do trabalho de Zinberg (1984) promovida acima, nos coloca a par da importância do contexto social para a compreensão do uso de drogas. Este ponto de vista nos permitiu dar um passo adiante do próprio Zinberg e percebermos a profunda atração do contexto social de uso do crack como um grande elemento agregador de parcela importante da população em situação de rua da cidade de São Paulo. Neste sentido, o prazer de estar entre pares interagindo pela conversa de temas próprios ao cotidiano como usuário de crack deve também ser levado em consideração, como ocorre nas "communitas" estudados por Victor Turner.

\section{A "communitas" em torno do uso do crack}

A “communitas"97 espontânea, como tratada por Victor Turner a partir da análise de obras literárias e exemplos históricos, será

97 Manteremos a palavra "communitas" entre aspas conforme faz Victor Turner. 
por nós aqui utilizada como recurso analítico para compreender o ambiente proporcionado pelo uso do crack e sua atração sobre os craqueiros. Serão focados três locais distintos: uma "biqueira" com fumódromo a céu aberto, a Cracolândia paulistana e uma "biqueira" com fumódromo em local fechado. O local de uso de crack pode ser visto em Malheiros $(2012,2013)$ como espaço de socialização no consumo da droga desde sua aquisição. Em Saporti; Sena; Silva (2010) o local de uso aparece como articulado à rede de empreendedores e de "bocas". Ele pode também figurar como espaço repleto de personagens abjetos. (RUI, 2012, p. 11) Uma visão mais generalizadora, para além do consumo de crack, concebe os locais de uso de drogas como contextos sociais capazes de prover um ambiente mais ou menos propício ao uso controlado. (ZINBERG, 1984) Finalmente, como em Grund (1983) e Alves (2014), o local de uso seria também um espaço onde a estrutura de vida do usuário teria influência sobre seu padrão de uso.

Nossas análises e conclusões são provenientes de uma observação participante entre usuários de crack da região central da cidade de São Paulo, mais especificamente nas regiões do Cambuci e nas proximidades da Estação da Luz, área também conhecida como Cracolândia. São locais de comércio e uso de substâncias psicoativas tornadas ilícitas, "territórios psicotrópicos” (FERNANDES; PINTO, 2004, p. 149), ou seja, interstícios espaciais apartados do cotidiano urbano regido pelos mercados de produtos e serviços legais. Um valor importante, como visto anteriormente, é o de preservar os não usuários do impacto provocado pela visão do consumo de crack; para tanto, recorre-se às tecnologias disponiveis na rua a fim de se obter abrigo e intimidade. Um dos locais de comércio e uso de crack por nós pesquisado é uma "biqueira", como se chamam os locais de venda de substâncias psicoativas tornadas ilícitas na cidade de São Paulo, com fumódromo a céu aberto. Isto significa haver lá comércio e uso constante do crack. Localiza-se em um 
beco, travessa da rua São Paulo e às margens da Avenida Radial Leste, no bairro do Cambuci. O uso de crack no local pode aglutinar mais de uma centena de pessoas e havia lá, cerca de dez barracos.

Sabemos que o barraco é a principal tecnologia disponivel na rua para o abrigo e proteção. Sua constituição é tão variada quanto são os materiais disponíveis, habilidades, propósitos e gostos pessoais. Surge, então, um ambiente íntimo, adequado para o uso seguro da droga, livre da vergonha de se estar agredindo os valores dos passantes, assim como da "radiação" vinda de fora. O ambiente externo ao barraco está na verdade amplamente interligado a ele, porque a "biqueira" com fumódromo a céu aberto é um lugar extremamente agitado, onde a troca recíproca de todo tipo de bem e serviço é constante. O barraco é suficientemente permeável a ponto de possibilitar a requisição de bens e serviços disponiveis no lado externo e ao mesmo tempo acompanhar alguma agitação maior na rua.

O barraco de alguém pode ser limpo e consertado por terceiros, tais serviços entrando no circuito da "treta". Não apenas os serviços, mas o próprio barraco pode ser vendido, trocado ou alugado. Ter um barraco em boas condições e muito frequentado é quase sempre garantia de acesso perene à pedra de crack. Sua construção e manutenção estão em consonância com a rua ou baixo de viaduto onde é erguido, sendo que antes do DBA, programa municipal dedicado à oferta de serviços aos usuários de crack, eles eram uma presença constante na Cracolândia.

A Cracolândia é um espaço de uso e comércio intenso. Compreendia, no início de nossa etnografia em fevereiro de 2013, parte da rua do Triunfo e rua dos Gusmões, assim como o quadrilátero entre a Alameda Glete, a Avenida Rio Branco, a Avenida Duque de Caxias e a Alameda Cleveland. Neste espaço, entre a Praça Princesa Isabel e a Estação Júlio Prestes estão o Largo Coração de Jesus e a Praça Júlio Prestes. 
Diferente dos dois locais de uso de crack brevemente descritos acima, a "biqueira" a céu aberto e a Cracolândia. Também pôde ser pesquisado por nós, o uso coletivo do crack em uma "biqueira" com fumódromo em local fechado. Trata-se de um cômodo construído em terreno murado, juntamente com outros poucos imóveis do mesmo tipo, localizado no bairro paulistano do Cambuci, em frente a um edificio ocupado por sem tetos. Um espaço fora da legalidade e isento dos deveres quanto aos padrões de construção, assim como dos direitos aos serviços de saneamento básico, constituindo-se, portanto, em um lugar intersticial. Nele, mãe e filha habitam e fazem uso de crack. A filha comercializa a pedra e a mãe trabalha como catadora de material reciclável. Muitos amigos circulam pelo local e ali fazem uso do crack, mas uma senhora se destaca pela maneira afetuosa como é tratada por todos: ela é carinhosamente chamada de Vó.

A conversa costuma fluir por toda noite, enquanto se fuma e vende pedras. Os cachimbos são constantemente modificados e reparados como é comum em qualquer roda de crack. Chama a atenção o cuidado com o trato do cachimbo de Vó por parte da traficante, aqui chamada de Amélia, a mesma interlocutora supracitada no início deste livro. Observo-a em seus movimentos precisos, ligeiros, enquanto desmonta e monta o "chimbó", um codinome para cachimbo de fumar crack. Ela retira a borra, prepara novas doses de pedra para si e para outros, principalmente Vó. Ao reparar o “chimbó” de Vó, Amélia age certamente movida por compaixão, porém, seu ato nos leva a pensar sobre sua habilidade artesanal. Proporcionar o máximo de absorção de fumaça a uma pessoa querida através da manutenção do cachimbo é a dimensão instrumental de sua ação. Porém, o pedido de Vó para que seu "boris" lhe fosse devolvido logo e a insistência da artífice em contrariar e ralhar com a pessoa que quer agradar, revela um desejo que poderíamos considerar próximo do "trabalho bem-feito por si mesmo” (SENNETT, R., 2012, p. 19), do artífice. À compulsão 
pela pedra, poderia acrescentar-se a obsessão pela perfeição? Produtora e usuária do cachimbo, envolta em um ritual voltado à maximização do fruir da pedra com a redução dos demais desejos, Amélia come pouco, não arruma seu barraco além do mínimo necessário à recepção de outros igualmente interessados na absorção da fumaça e bebe quase nada. Coisa nenhuma poderia estar mais longe de alguém entregue à satisfação desmedida dos desejos; nossa "usuária forte"98 se assemelha a uma asceta como S. Francisco de Assis.

Estas observações a respeito do trabalho voluntário feito fraternalmente por Amélia, traficante em uma "biqueira" em local fechado, assim como das trocas correntes no interior e exterior dos barracos em uma "biqueira" a céu aberto e na Cracolândia. Levam-nos a propor uma maneira de pensar o ambiente possibilitado pelo uso do crack, a partir da qual seja possivel lançar alguma compreensão a respeito de seu apelo e atração sobre os craqueiros para além da fissura proporcionada pela droga. Este apelo foi descrito pela autora de maior sucesso na literatura sobre o uso de drogas, Christiane Vera Felscherinow, ou simplesmente Christiane F. Ela relatou, no momento de elaboração deste trabalho, ainda com 53 anos de idade, ressaltando a relação do contexto social para o usuário de drogas através do seu segundo livro publicado em 2014, de onde tiramos esta breve citação:

Muitas vezes a causa de tudo isso não era apenas a heroína, mas o contexto social. Em determinado momento, mesmo sem a gente se dar conta, a vida passa a funcionar de tal maneira que nos leva sempre aos mesmos lugares e a repetir os mesmos comportamentos. E não me refiro apenas ao vício, mas também às outras coisas que sistematicamente nos fazem voltar à droga. Comigo, por exemplo, o problema de tudo isso no fundo é que não suporto ficar sozinha. Voltei então aos meus antigos conhecidos do reduto, mesmo que não fossem realmente amigos. Eles

98 Termo utilizado para designar usuários de grandes quantidades de crack. 
Jamais fomos zumbis

tinham o mesmo tipo de ocupação, de problemas e de histórias a contar que eu. Tudo isso propiciava uma rápida aproximação e a gente tentava chamar isso de amizade. (FELSCHERINOW; VUKOVIC,2014, p. 153, grifo nosso)

Esta senhora, cujo uso de drogas na juventude a levou a ser uma grande referência para sua geração - na qual o autor deste livro se inclui - percebeu claramente (e não poderia ser diferente visto sua experiência de 40 anos com o uso de drogas) a importância da atração exercida pelo contexto social na manutenção de certo padrão de uso. Nossa pretensão aqui é procurar na ideia de "communitas" uma chave capaz de nos proporcionar meios analíticos para desvendar o fascínio do ambiente que envolve o usuário de drogas, particularmente o crack.

As relações sociais dentro de determinado contexto social não devem ser consideradas apenas em sua forma socioestrutural. Outras modalidades, como a "communitas", servem de base para a constituição de relações sociais entre indivíduos não segmentados em posições sociais. Nesta forma de se relacionarem, os indivíduos podem interagir com autêntica reciprocidade. Marcada pela espontaneidade e imediatidade, a "communitas" opõe-se ao caráter jurídico/político da estrutura. Malgrado a satisfação que os participantes possam derivar de tal situação, a "communitas" estaria, por razões materiais de sobrevivência do grupo, condenada a ter uma vida curta e, em decorrência disto, as relações entre indivíduos retornariam a relações normatizadas entre "pessoas sociais". (TURNER, 1974, p. 161)

A roda de crack aproxima-se de uma das formas de apresentação da "communitas" conforme classificação de Victor Turner, que oferece como exemplo, a "communitas" existencial, correspondente aos happenings dos hippies dos anos 1960 e início dos anos 1970, nos EUA. Ela seria uma experiência de reciprocidade imprevisivel e única. Os hippies buscariam este estado de liminaridade, de estar no limite entre dois estados diferentes de 
existência, através do uso de drogas empregadas para "expansão do pensamento". (TURNER, 1974, p. 168) Não apenas as sociedades pré-letradas, mas também as sociedades complexas e estruturadas seriam entrecortadas por momentos de liminaridade espontânea, nos "intervalos entre os encargos das posições e condições sociais”. (TURNER,1974, p. 168) Os momentos de lazer e recreação, como os shows de rock, com suas luzes, som em alto volume e consumo de drogas, seriam para Turner oportunidades para se criar uma comunhão de uns com os outros. Esse seria um estado de completa reciprocidade e profundamente transformador, no qual se poderia ir até o íntimo de cada um e aí encontrar algo de intrinsicamente comunal e compartilhado. Uma existência em êxtase, ou seja, fora das normas e suas posições estruturais. Assim, a "communitas" aparece como uma grande tentação humana, a tentação do gozo dos sentimentos prazerosos proporcionados pela liberação das inclinações pessoais das amarras dos desejos e necessidades do social estruturado. Haveria, portanto, na "communitas" algo de mágico, capaz de proporcionar uma sensação de poder ilimitado, balizado apenas pela imposição mínima de limites para salvaguardar a existência; encontrar a relação ótima entre "communitas" libertadora e estrutura supridora constituiria o grande desafio dos envolvidos neste tipo de empreitada.

Um modo particularmente interessante de "communitas" existencial teria sido a vivida por S. Francisco de Assis e analisada por Turner. Nela, uma determinada concepção de pobreza foi colocada em prática e gerou certas atitudes com relação à propriedade. O ideal de $\mathrm{S}$. Francisco para a convivência com seus frades era o da completa desvinculação com o "sistema comercial do mundo" (TURNER, 1974, p. 175) e com os negócios seculares, voltando-se para a convivência entre os pobres, fracos, doentes e pedintes, até os limites da necessidade. Estes limites eram alcançados pelo deliberado apartamento do mundo comercial, com a vida suprida por recompensas as mais incertas 
possíveis como as da mendicância. Este seria, segundo Turner, o modo de vida buscado por certos hippies norte-americanos da virada das décadas de 1960-1970, particularmente aqueles em torno da famosa esquina de Haight-Ashbury - na cidade coincidentemente chamada de S. Francisco - sendo que o consumo de drogas também estaria profundamente ligado a esta perspectiva.

A procura por viver da mendicância, fora da vida comercial, seria um esforço para manter-se na liminaridade, nos interstícios da vida social daquele tempo vivido por S. Francisco e por seus frades. Neste espaço, a "communitas" poderia surgir. Ao entregarem-se nas mãos da providência procuram seguir o exemplo do Cristo nu e crucificado, ele próprio tendo vivido de esmolas, juntamente com sua mãe e discípulos. A fuga da propriedade era também a fuga da estrutura, pois os dois, propriedade e estrutura estão intimamente interlaçados nas formas sociais duradouras com sua estruturação e rotinização.

Nas duas "biqueiras" que frequentamos, assim como na Cracolândia, as "pessoas sociais" (TURNER, 1974, p. 161) eram representadas por aqueles com maior proximidade com o tráfico de drogas, na posição de "vapor" ou traficante. Porém, no caso de nossos interlocutores, sua posição como traficante, quando havia, estava mais próxima aos interstícios da estrutura do tráfico. Era uma posição extremamente frágil, mais próxima de um usuário/ "vapor" e não de um membro fixo em uma estrutura estabelecida. Seus valores se confundem com os valores dos demais usuários, a reciprocidade na "treta" se aplica também a eles. Compartilham as mesmas condições de vida, embora o "vapor" esteja mais sujeito às regras do crime organizado quanto à permanência na "biqueira" e também um pouco mais atrelado a deveres estritos de prestação de contas quanto à quantidade de pedras vendidas.

Comentamos até aqui, apenas duas "pessoas sociais" encontradas em "biqueiras", a de "contenção" e "vapor". Para o contexto da Cracolândia, poderíamos acrescentar as posições de 
sintonia, "disciplina", "primo" e "irmão" do PCC. Porém, é necessário salientar a plasticidade destes termos, que podem dizer respeito a realidades diversas, a depender do contexto vivido, como no caso "do sintonia e contenção". Na roda de crack, "sintonia" é a agradável sensação de fraternidade entre todos os participantes, sensação primordial à ideia de "communitas". Já na Cracolândia, o termo pode referir à "pessoa social" responsável pela segurança. Na "biqueira" a céu aberto da rua São Paulo, "contenção" é o responsável por receber quem chega; na "biqueira” em local fechado também havia alguém nesta posição. Já na roda de crack, "contenção" pode ser o termo designativo daquele responsável por buscar água, cigarros e Bic, caso estes acabem e até mesmo de colocar as pedras de crack nos cachimbos para garantir quantidades equânimes aos participantes da roda. Aí, existindo uma verdadeira cooperação "como uma troca em que as partes se beneficiam". (SENNETT, 2012, p. 15)

A “communitas" é fugaz e liminar; tenderá sempre a retornar à estrutura. Assim, com o tempo, a "communitas" espontânea cede às pressões por normatização devido à

"necessidade de mobilizar e organizar recursos e da exi-
gência de controle social entre os membros do grupo na
consecução dessas finalidades, a 'communitas' existencial
passa a organizar-se em um sistema social duradouro".
(TURNER, 1974, p. 161)

$\mathrm{Na}$ "communitas" normativa e duradoura está presente o imperativo de mobilizar recursos para o provimento das necessidades da vida, bem como o de mobilizar pessoas através de algum tipo de organização social com relações estruturais, comando e obediência. Já na "biqueira" da rua São Paulo, na de Amélia e na Cracolândia, o recurso advindo do "corre" individual pertence a quem o produziu e esta relação com a propriedade - como vimos no caso dos frades franciscanos - é fundamental para não deixar florescer "as sementes da segmentação e da hierarquia estruturais”. (TURNER, 1974, p. 166) Estamos, 
portanto, muito próximos a uma situação de igualdade, em um happening socialmente transitório proporcionado pelo uso de crack e pela fruição da "sintonia" como sentimento de fraternidade por todos os participantes da roda.

Na Cracolândia, antes do Programa DBA, a estrutura mais próxima aos usuários de crack era representada pelas "pessoas sociais" dos "disciplinas", "primos" e "irmãos" do PCC. ${ }^{99}$ As relações diretas e imediatas entre indivíduos poderiam ser vividas no interior do "fluxo" e nas rodas de crack. A atração do "fluxo" é devida ao seu aspecto "communitas", ou seja, indivíduos em relação direta uns com os outros, conversando em pequenos grupos e movimentando-se entre eles. O passar das horas se dá entre velhos e novos conhecidos, todos animados pelo exercício da treta - troca recíproca de bens variados afeitos ou não à parafernália de uso do crack - e pela "sintonia" proporcionada pelo uso.

Como pudemos presenciar, ao serem convidados a entrar em um estabelecimento comercial (como um bar ou lanchonete), usuários de crack costumam recusar o convite. Esta recusa, muitas vezes longe de ser envergonhada, mais comumente ocorre de modo orgulhoso, quase indignado. ${ }^{100}$ Entrar em qualquer bar, que não seja um daqueles pouquíssimos locais disponiveis no interior da Cracolândia, mais especificamente na rua Dino Bueno, é visto como comportamento de "Zé Povinho" e não de quem "é do crack". Tal qual frades a acompanhar S. Francisco, nossos interlocutores craqueiros romperam os laços com o sistema comercial, em um estado liminar e estabilizado de pobreza "levada até os limites da necessidade".

99 A polícia e os agentes do SUS pertenciam às suas estruturas próprias e estavam presentes na cena, mas não se encontravam abertas à participação dos usuários de crack em seu interior.

100 Presenciamos uma usuária ser expulsa do bar onde nos encontrávamos, por intencionar banhar-se no toalete do estabelecimento. É claro que estas situações também criam uma aversão da população em situação de rua a tais ambientes. 
(TURNER, 1974, p. 176) Assim, se os franciscanos da época de S. Francisco pediam esmolas, nossos craqueiros podem passar seus dias "mangueando". ${ }^{101}$ Livres da propriedade, libertam-se da estrutura, que fica relegada aos "vapores" e "contenções" contadores de dinheiro e prestadores de contas ao tráfico. A acumulação de bens é desencorajada pela própria cultura de uso. Os usuários de crack, que em algum momento de sua "caminhada" chegam a ter acesso a somas maiores de dinheiro, costumam utilizá-la no consumo da pedra até o esgotamento dos recursos financeiros.

O uso do crack é coletivo nos locais observados durante nossa pesquisa. Este uso possibilita a vivência de uma sociabilidade semelhante à "communitas" espontânea procurada, tanto pelos hippies quanto por S. Francisco de Assis. Nela, a pobreza é algo fundamental, que permite a manutenção de um estado desestruturado das relações sociais e possibilita relações fraternais entre despossuídos, marcadas pela reciprocidade das trocas na "treta" e menos afeita a relações baseadas em "pessoas sociais" com funções estruturadas. Essas são mais ligadas aos membros muitas vezes circunstanciais do tráfico de drogas, como o usuário/“vapor". Longe de ser "uma substância que dá à pobreza acesso ao sonhado consumo contemporâneo" (MEDEIROS, 2010, p. 182), o crack abre as portas para a negação deste consumo e para a vida em "communitas".

\section{Período e frequência de uso: o zumbi desmascarado}

Seja pelo seu aspecto às vezes maltrapilho, seja pelo seu comportamento destemido ou pelo olhar vidrado e sem vida, a mídia encarregou-se de caracterizar os usuários de crack como zumbis ou mortos vivos. (BOES, 2011) É como se houvessem cometido suicídio ao valerem-se da "droga que mata", mas permanecessem ainda meio vivos, moribundos, à espera da morte certa. Po-

101 Nome dado ao ato de pedir esmolas na rua. 
rém, se o termo faz algum sentido, é porque parece haver algo no comportamento dos usuários passivel de ser associado aos autômatos mal finados dos filmes de terror. Exponho abaixo, um pequeno trecho de conversa com Zezé, em seu barraco. Trata-se do artista plástico carioca, na faixa dos 45 anos, com cerca de uma década de uso de crack, citado anteriormente.

Zezé - Não. Usuário de crack só tem obrigação com a próxima pedra.

Ygor - Mas, às vezes o credor precisa pagar alguém de onde ele pegou o bloco.

Zezé - A virada não é essa. Geralmente, usuário de crack, ele não usa o que recebe pra pagar o que deve. Entendeu? Ele quer a pedra. Ele deve $R \$ 50,00$, mas ele só tem $R \$ 10,00$, ele não pensa vou pagar $R \$ 10,00$ para ficar devendo só $R \$ 40,00$, não, ele vai querer fazer a pedra porque o corpo exige.

Ygor - Mas aí como é que faz? Fica sempre endividado?

Zezé - Não, ele depois de acordar, quando a gente fala 'acordar' é que quem costuma usar o crack, fica muitas horas sem se alimentar, sem dormir [...] Não tem uma dobra natural no nosso pé? Quando a gente fica três, quatro, cinco dias virados sem dormir, a gente tá caminhando muito, nesse caminhar essas fissuras naturais do nosso pé acabam virando uma ferida. Isso é o pormenor, o pormenor.

Ygor - Ah, certo.

Zezé - Outra. Depois de muitos dias, a gente tem vontade de usar mais e o corpo pede, às vezes quando fica um intervalo sem fumar, o cara pega e descansa, começa a desligar. Você acaba dormindo. Quando vê uma pessoa estirada em qualquer lugar, sem nenhum conforto, deitado, dormindo é porque o corpo desligou.

Ygor - Sei.

Zezé - Sabe quando o combustivel do carro está na reserva. Tem combustivel, mas tá marcando reserva, [...] Você vai subir uma ladeira e aí, no meio da ladeira acabou a gasolina.

Ygor - Sei.

Zezé - E agora? Ou você freia ou deixa o carro descer. É o que acontece com o usuário. Ele apaga, o corpo apaga. 
Todas as imagens que a gente fica vendo e ouvindo parece um filme. É como se você estivesse sonhando acordado.

Ygor - Ah, fica de olho aberto, mas apagado?

Zezé - Não. O consciente fica um pouco inconsciente, psicologicamente falando, entendeu? Você lembra-se de quando você estava dormindo, mas sonhou e quando você acordou você soube que aquilo que você pensava que era realidade, na verdade era um sonho. Isso acontece conosco diariamente, acordado caminhando.

O usuário é perfeitamente capaz de refletir sobre suas adversidades (MALHEIROS, 2013) e a condição de zumbi, ou o estado físico e mental capaz de gerar a atribuição deste termo aos usuários, é uma circunstância específica em uma "caminhada", um apagar.O corpo "exige" a pedra, com uma intensidade proporcional à sequência de dias despertos e dedicados ao crack. Porém, mente e corpo não se apagam necessariamente no mesmo instante e, na medida do cansaço de um, está o esvair do outro. Ao corpo fatigado, sedento e faminto corresponde uma mente propícia a sonhar acordada e despertar, para depois sonhar outras vezes até finalmente desligar. Portanto, o estado comparável ao zumbi, ou seja, aquele no qual se sonha acordado, não diz respeito à totalidade do que chamamos de "Ciclo alerta/sono do usuário de crack", mas apenas a uma parte; mais especificamente àquela correspondente ao estado de movimento do corpo durante o sonho provocado por dias e dias de uso em estado alerta. Atribuir ao usuário de crack a alcunha de zumbi é tomar um estado particular de sua existência cotidiana e tê-lo por totalidade. Este estado é sucedido pelo sono propriamente dito, com o corpo em estado de repouso para em seguida poder despertar com a "mente limpa", ou seja, pronta para um "trago" mais prazeroso. ${ }^{102}$ Neste sentido, corpos e mentes são vistos como um só. À mente alerta, corres-

102 Conforme nos declarou o ex-usuário Antônio, o trago ao despertar, ou seja, aquele dado "com a mente limpa" é mais prazeroso quando comparado àqueles dados apenas para manter-se acordado. 
ponde um corpo em movimento, ao corpo fatigado, corresponde uma mente que sonha acordada. Esta, por vezes, pode estar mais desperta ou mais absorta em um sonho. A percepção embaralhada tem na realidade, o sonho e, no sonho, a realidade. Ele pode despertar e voltar a sonhar por inúmeras vezes e o corpo permanecerá em movimento, a acompanhar o usuário de crack em sua "caminhada". Ao cair definitivamente em um sono profundo, deitado em uma calçada ou mal acomodado em seu barraco, o usuário estará em condições de descansar um pouco mais profundamente, porém, para isso, pagou o preço de ir desfalecendo gradualmente em um longo processo de luta por permanecer um pouco mais semiacordado à custa do consumo de pedras de crack. Assim sendo, o que comumente se chama de binge, o uso de drogas até o completo esgotamento, pode ser mais bem conceituado ao se levar em conta o usuário, seu corpo/mente em um ambiente a proporcionar pedras de crack. Pedras estas obtidas a partir do movimento do "corre" e necessárias para manter um corpo/mente alerta até o embaralhamento de sonho com realidade. Se o uso de drogas em geral nos permite ter uma nova percepção da realidade, o uso do crack permite mesclá-la com nossos sonhos em um ambiente onde tudo parece conspirar para dificultar o descanso.

Figura 39 - Ciclo alerta/sono do usuário de crack

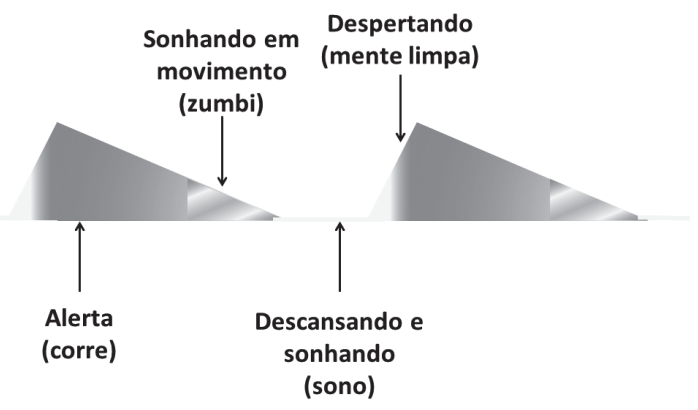

Fonte: Coleção particular do autor. 
A quantidade de pedras fumadas em um dia foi estimada por mais de um usuário em 15 unidades e, os intervalos entre os "tragos" costumavam durar em torno de 15 minutos. Como podemos observar na fala de Zezé: "Vou precisar de outro 'trago', pra compensar o que eu perdi depois de 15 minutos aqui pra dar o 'trago', mas não vou dar neste cachimbo, vou preparar este aqui". Um "bloco" costuma proporcionar seis "tragos" e 15 "blocos", 90 "tragos". Ou seja, 15 minutos de intervalo entre um e outro "trago", são 22 horas e 30 minutos de uso ${ }^{103}$ ininterrupto. Anos de prática parecem proporcionar ao craqueiro uma medida exata de pedras necessárias para um dia satisfatório. Em um ciclo de uso de seis dias, com cinco dias de uso e um de sono, o usuário poderá consumir 90 pedras de crack ou dar 450 "tragos", desde seu despertar até cair no sono novamente. Isto, ao custo de $R \$ 10,00$ a pedra, sai por $R \$ 900,00$. Bancar esta imensa despesa no ambiente da rua, só se torna possível pelas trocas generalizadas existentes do circuito da "treta".

Em um estudo sobre usuários de crack em El Barrio, ${ }^{104}$ na cidade de Nova Iorque, foi encontrada uma frequência de uso de até um "trago" a cada 2,30 minutos . (BOURGOIS, 2006) Ser um "usuário" e não um "nóia” é algo considerado importante pelos nossos interlocutores. O último é vinculado à falta de autodomínio, enquanto o primeiro seria capaz de domar sua vontade e usar a droga em quantidade e frequência controladas. (ZINBERG, 1984)

Mas tudo depende do corpo. Um corpo "virado", dois, três ou mais dias, vai perdendo a capacidade de dominar suas necessidades. A vontade é atributo do corpo descansado e alimentado. Capaz de "fazer seu corre" e não ser "parasita", não ser "frango" como o usuário iniciante, "dragão" incapaz de dar

103 Caso fosse dado pelo usuário, um trago a cada 16 minutos, 90 tragos corresponderiam a exatas 24 horas.

104 Nome dado pelos moradores à região de East Harlem, pesquisada por Bourgois. 
um "trago" comedido e honrar suas obrigações com os parceiros. A reciprocidade, como prática e como valor, é colocada em cheque pelo corpo; este pede a pedra para resistir à fadiga, contra os ditames da "sintonia", sinônimo também de reciprocidade. O equilíbrio só é reencontrado na possibilidade de se ter o sono e depois acordar. A obrigação com o "parça" volta a suplantar a "obrigação com a próxima pedra" que segundo Zezé, seria a única motivação do craqueiro esgotado. Manter-se no domínio da vontade é uma função da maior ou menor fadiga do corpo e da mente.

Isto coloca em discussão como vimos logo acima, a dinâmica do chamado binge de crack, ou seja, seu padrão de consumo crônico, por dias, sem alimentação ou sono, terminando apenas com o usuário exaurido, ou sem a droga. (NAPPO, 2004) Enquanto usa drogas por dias seguidos, o usuário está no "corre", exerce diversas atividades segundo papéis e relações sociais mais ou menos definidos. Ele também se alimenta para auxiliar a controlar a frequência de uso (SILVA, 2000), tanto no início do ciclo, como vimos acima com Zezé, ou mesmo em seu final, antes do sono, como segue abaixo com Antônio, um ex-usuário, com experiência de viver em situação de rua.

Antônio - Um cara chegou pra mim, 'tá [sic] aqui, vou te dar duas, pra você trazer pra mim uma coisa'. Eu falei, 'segura essas duas, eu não tô conseguindo fumar'. Eu não estava conseguindo fumar. Tava com fome. Com fome e com sede [...] Eu tava quatro dias sem comer, chega uma hora que a fome bate e você não tá nem aí. Tô nem aí, pô [...] Aí, ele pagou um lanche. Eu comi. Comi aquele lanche. Me acabei. Deitei e dormi. Dormi até o outro dia.

Ao pensar na frequência de uso encontrada entre os frequentadores da Cracolândia, deve-se levar em conta que ela se altera durante o binge e este uso se dá, na maioria das vezes, em uma roda de crack e não de modo solitário. (VIEIRA, 2010) 
Este modo requereria que o usuário tivesse todo o "maquinário" à sua disposição e o eliminaria do circuito da "treta", da reciprocidade e da "sintonia". Isso lhe roubaria um aspecto fundamental do prazer de fumar, parafraseando Timothy Leary, aquela sensação de cumplicidade prazerosa daqueles que compartilharam a mesma pedra imprimindo bons sentimentos uns nos outros. (LEARY, 1999, p. 164) Se não considerarmos essa dimensão do prazer, nossa compreensão das motivações do usuário fica restrita apenas ao uso do crack, ou mais errôneo ainda, ao alívio da fissura.

Estes e outros aspectos da realidade vivida pelo craqueiro só podem ser observados no campo e ficam inacessiveis às pesquisas com usuários institucionalizados, ou convidados a dar entrevistas a pesquisadores em ambiente acadêmico. Vimos no decorrer deste livro como, nas cenas de uso, os usuários escolhem entre diversas qualidades da droga e múltiplos ambientes para manipularem os efeitos ou "brisa", segundo as diversas oportunidades abertas pelos seus múltiplos estados corporais em interação com ambientes variados e seus inúmeros usuários. Sabemos que os padrões de uso passam por diferentes gradações na carreira de cada usuário e ao mesmo tempo dependem dos imponderáveis do cotidiano, variando do padrão controlado ao "se deixar levar".

Acima de tudo, deve-se atentar para a maneira como as práticas de uso se enquadram em uma ritualidade complexa de trocas materiais e simbólicas, variável com a disponibilidade da droga, ambiente físico, maior ou menor prestígio dos envolvidos e as possiveis ameaças que possam se apresentar, provenientes de diferentes fontes, mas sempre presentes no contexto da ilegalidade. Os efeitos do uso do crack, denominados pelos usuários de "brisa", dependem do ambiente de consumo, e podem variar desde sensações agradáveis e prazerosas, acompanhadas de disposição para as mais diversas atividades, sejam 
elas voltadas ao trabalho ou à sociabilidade, até a "paranoia", onde prevalecem movimentos repetitivos e o desprazer. Entre estas possibilidades, com suas múltiplas gradações, os usuários manipulam o corpo, o ambiente e a droga, segundo sua vontade e as possibilidades que se oferecem. 